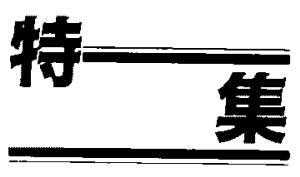

\title{
トリチウムの影響と安全管理
}

\section{Radiation Effects and Safety Control of Tritium}

\begin{abstract}
国際熱核融合実験炉(ITER)の咩細設計が終盤にさしかかっており，安全性に対する関心も高まっている。核融合炉 の女全性の確保に関しては，特にトリチゥムの影響評価と安全管理がきわめて重要である。本特集では,トリチウムの 生物影響, 環境影響, 女全管理に関する最新の研究状況之知見を紹介する。 (担当編集委員·吉田 真)
\end{abstract}

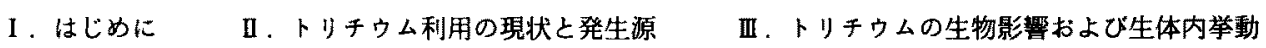

IV. 環境中トリチゥム挙動 V、安全管理とモニタリング

\section{I.はじめに}

茨城大学 一 政 祐 輔*

我が国の核融合開発研究は，日本原子力研究所(原研)で はJT-60が1996(平成 8)年10月に臨界プラズマ条件を達成 し，文部省核融合科学研究所の大型へリカル装置 (LHD) の建設は1997年に完成するなど，活発に行われている。

国際熱核融合実験炉(ITER)計画は国際協力の下で作業 が進められているが，設計にあたってその環境に対する安 全性は充分に考慮され，米国，EC，ロシア，日本の 4 極のよ゙ の国へむ受入れ可能な実験炉として開発されてきた。1996 年12月にITERの詳細設計報告書が出されて設計は終盤に さしかかるにつれて，サイトをどこの国に設置するかが話 題になっている。しかしITERではその然料にトリチウム を使用することからトリチウムの環境安全性が注目され， 設計が見実化するにつれて，安全性に対する国民的関心す 高まってきている。

炉設計についての研究が進められる一方において，国際 的なトリチゥム環境動態・評価に関する研究プロジェクト に関しては、1991年に始まったトリチゥムの環境動態につ いての会議「BIOMOVS (BIOspheric MOdel Validation Study-Phase II，放射性核種，他微量物質の環境中におけ る移行よ生体蓄積の定量化のために構築されたモデルの検 証に関する国際共同研究」が1996年10月に完了して，同じ 会議の席上で新たにIAEAに事務局を置いた次期国際共同 事業「BIOMASS(BIOsphere Modelling and ASSessment methods)」が発足した。このプロシェクトの目的はBIOMOVS I とワの流れを継承しているものの，環境中での 放射性核種の移行過程を如何にしたらより実際に合ったモ デルに表見できるのか，その評洒の手法，技術に関する国 際的なコンセンサスを得ることに重点を置いたものであ る。この中でトリチゥムの占める位置は重要であることか ら，他の核㮔についての作業に先駆けてトリチウムの作業

- Yusuke ICHIMASA, Ibaraki Univ. (1997年 9 月12日 受理)
グループが1996年10月に同時に結成され(第 1 回会合), ト リチゥムのみの第 2 回の会合を1997年 4 月にフランスのカ ダラッシュでフランスのイブ・ベロー氏を主查に開催され た。BIOMASSの第 2 回の全体会議は1997年10月にウィー ンで開催される。1998年 4 月にはトリチウムのみのワーキ ンググループの会議がカナダで開催されるとの情報むあ り，目まぐるしい動きがある。

1992年 7 月には，米国，EC，カナダと日本の間でIE A核 融合環境・安全性および経済性に関する研究協力が開始さ れた。そのうちの一つのタスクとしてトリチウムの安全性 と環境影響がある。この研究協力の一環として，1994年に カナダに怙いてトリチウムガス野外連続放出実験が実施さ れ，日本6参加した。また，1995年6月にイタリアで第 5 回トリチウムに関する国際会議」の折りにも IEAの会議 が開催され原研と大学から参加した。

このような国際的な研究動向に対して，我が国としてあ 1995年と1996年度には文部省科学研究費総合研究(A)によ る「重水素野外放出実験」を大学, 核融合研，原研，放医研の 合同研究班で害施し，1997年度からは引き続き文部省科学 研究費基盤研究(A)で, 文部省核融合科学研究所の LHD計 画共同研究のネットワークを活用しながら，より完全なト リチウムの安全管理を目指して，重水を野外でのトレーサ とするトリチウムの環境影響評価の研究が行われている。

JT-60，LHD，ITERなどによる研究の情勢を反映して, トリチウムの環境安全性に対する関心が高まっていること から，本特集ではこれまで明らかになっている最新の研究 状況と知見を紹介することとした。特集記事の計画にあ たって，誌面の都合から，トリチウムの生物影䇻について は生物学的效果比(RBE)とトリ千ウムの線量係数につい てのICRPの考え方を紹介するに留めた。生体内動態につ いても個々の現象について触れるのはやめて, トリチゥム の生体内動態とそのモデルのみを取り上げた。次に環境中 トリチウム挙動の項目では，環境に存在する天然トリチウ ムの挙動，および核実験で生成したトリチウムの分布と娍 衰の状況, 土壌・水圏・植物中におけるトリチウムの挙動, またこれらのトリチウムの食品から生体への分布, 安全性 
を確保するための線量評価モデルについて紹介した。トリ チウム取扱い施設においてはトリチウムの安全管理とも二 タリングが極めて重要であることから，トリチウムの安全 取扱い技術, 廃棄物管理および処理技術, 施設内モニタリン グ技術，環境中モニタリング技術，個人モニタリング技術を 紹介することとした。

\section{II.トリチウム利用の現状と発生源}

\section{日本原子力研究所 野口宏*}

\section{1. 環境中トリチウムの発生源}

環境中にはすでにトリチウムが存在しているが，そのト リチウムには天然起源のもの之人工起源のあのがある。天 然起源のトリチゥムの大部分は，上首大気中における宇宙 線之窒素や酸素との反沁によって生じたものである。ま た，人工起源のトリチゥムには，核実験起源のあの，原子 カエネルギー利用に伴うもの，医潦，産業，研究等に伴うも のがある。これらのトリチウムの発生量やインベントリー 等に関しては，岡田らがすでに詳細にまとめている(1)。こ のため，以下では天然核実験および産業等起源のトリチ ウムについてはその概略を述べるにとどめ，原子力や核融 合起源のトリチウムについて最新の状況をまとめる。

\section{2. 天然，核実験および産業等起源のトリチウム}

宇宙線によって生成されるトリチウムの大気中インベン トリーは，ほほ平衡状態にあると仮定すると，約 1.0 $1.3 \mathrm{EBq}$ であると，国連科学委員会(UNSCEAR)によって 評価されている( ${ }^{(2)}$ 。また，核実験によって環境中に放出さ れたトリチウムインベントリーの総量は，約 $240 \mathrm{EBq}$ と評 洒されている(2)。しかし，その後放射性朤壊により核実験 起源のトリチゥムインベントリーは隇少しており，1990年 現在で約 $52 \mathrm{EBq}$ と推定されている(1)。

トリチゥムは，医療，産業，研究等の分野においても多く 使用されている。わか国の統計によると，放射線障害防止 法の規制を受けている事業所が日本アイントープ協会を通 して購入した非密封トリチウムの年間量は，1995年度は約 $1.3 \mathrm{TBq}$ と報告されている(3)。1995年度のトリチウム使用

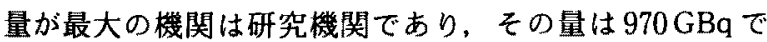
あった。ただしこれらの量には直接外国から輸入したも のは含まれていない。例えば，原研のトリチウムプロセス 研究室では直接外国から輸入しており，1997年 3 月時点の トリチウム保有量は約 $17 \mathrm{PBq}$ である。このトリチゥム量 は1995年度にアイントープ協会を通して購入されたわが国 の全トリチゥム量の10万倍以上である。

\section{3. 原子カ施設起源のトリチウム}

国内外の主な原子力関連施設から環境へ放出される年間

\footnotetext{
* Hiroshi NOGUCHI, Japan At. Energy Res. Inst.
}

トリチウム量す，UNSCEAR報告書にまとめられてい る(2)。最新データである1989年の統計結果を第 II -1 表に 示す。表には天然起源之核実験起源のトリチウムのインび ントリーも示した。こ机によると，世界中の原子力エネル ギーの利用に伴う1989年のトリチウム放出量の全合計は約 $24 \mathrm{PBq} / \mathrm{yr}$ であった。このうち最大の放出源はCANDU 炬 などの重水減速型原子炬 (HWR)であった。1 サイト当た りの最大放出施設はカナダのブルース原子力発電所にある 4 基のCANDU 炬で，1989年は合計 $2,324 \mathrm{TBq} / \mathrm{yr}$ の気体 状トリチウムを放出した。また，核燃料再処理施設(フラ ンスのラアーグ, 英国のセラフィールド, 日本の動燃東海再 処理施設の 3 ヶ所)加ら放出された気体状トリチウムの合 計は1989年は706 TBq/yrであった。しかし，そのうちの 約 $96 \%$ が英国のセラフィールド施設から放出されたあので あった。

現在, 我が国では青森県六ヶ所村に商用再处理施設が建 設中であるが，この安全評価において仮定されている放出 量は気体が約 $2 \mathrm{PBq} / \mathrm{yr}$ ，液体が約 $18 \mathrm{PBq} / \mathrm{yr}$ である(4)。気 体状卜リチゥムに関してはブルース発電所サイトと同程度 である。しかし，これらの放出量は安全評価のために仮定 した值であり，実際の運転ではかなり少なくなるものと予 想される。

\section{4. 核融合施設起源のトリチウム}

今後大量のトリチウムインベントリーを有すると考えら れる施設は核融合炉である。ヨーロッパのJET(Joint European Torus)や米国のTFTR(Tokamak Fusion Test Reactor)ではトリチゥムと重水素を用いた核融合実験

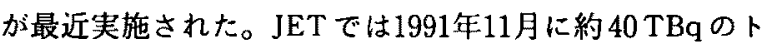
リチゥムを用いた実験が行われた(5)。その結果，1992年 3

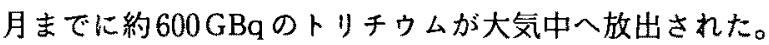
そのうちの80 90\%はトリチゥム水(以下，HTO)であっ たことが報告されている。また，スタックではトリチウム 化メタン(以下， $\mathrm{CH}_{3} \mathrm{~T}$ ) す検出されたが，その割合はわず

第 I-1 表 天然起源および人工起源の環境中トリチゥム インベントリーまたは放出量(1)(2)

\begin{tabular}{|c|c|c|}
\hline & 発生源 & $\begin{array}{l}\text { インベントリー } \\
\text { または放出量 }\end{array}$ \\
\hline \multicolumn{2}{|c|}{ 宇宙線による生成 } & $1.0 \sim 1.3 \mathrm{EBq}$ \\
\hline \multicolumn{2}{|c|}{ 大気圈内核実験(1990年時点の推定存在葦) } & $52 \mathrm{EBq}$ \\
\hline \multicolumn{3}{|c|}{ 原子力発電所(1989年) } \\
\hline \multirow[t]{3}{*}{ 気体 } & 加圧水型 & $201 \mathrm{TBq} / \mathrm{yr}$ \\
\hline & 沸騰水型 & $28 \mathrm{TBq} / \mathrm{yr}$ \\
\hline & 重水減速型 & $9,960 \mathrm{TBq} / \mathrm{yr}$ \\
\hline \multirow[t]{3}{*}{ 液体 } & 加圧水型 & $2.970 \mathrm{TBq} / \mathrm{yr}$ \\
\hline & 沸騰水型 & $34 \mathrm{TBq} / \mathrm{yr}$ \\
\hline & 重水减速型 & $3,440 \mathrm{TBq} / \mathrm{yr}$ \\
\hline \multicolumn{3}{|c|}{ 再処理起源(1989年) } \\
\hline \multicolumn{2}{|c|}{ 気体 } & $706 \mathrm{TBq} / \mathrm{yr}$ \\
\hline \multicolumn{2}{|l|}{ 湾体 } & $6,080 \mathrm{TBq} / \mathrm{yr}$ \\
\hline
\end{tabular}


かで0.04〜1.5\%であった。一方，TFTRでは，1993年12 月から1994年 8月までに合計約7PBqのトリチゥムが D-T 実験に使用された。その間にスタックから大気中へ放出さ れたトリチウム量は約 $5 \mathrm{TBq}$ と推定されている ${ }^{(6)}$ 。また, 実験期間中にスタックから放出されたトリチウムの化学形 は，大部分が元素状トリチゥムガス(以下，HT)であっ た。しかし，機器を除染するため，水分を含んだ空気を パージした期間はHTOの割合がHTの 2 ～ 3 倍となっ $た^{(7)}$ 。

国際熱核融合実験炉(ITER) は現在，工学設計活動が行 われている。1995年の中間設計報告書で想定されているサ イト内の全トりチゥムインベントリーは最大 $4 \mathrm{~kg}$ であ る(8)。ただし，第 1 壁の表面材料にカーボンが用いられた 場合は $5 \mathrm{~kg}$ 之推定されている。しかし，環境中へ放出さ れるのはこのうちのごく一部である。1996年12月に提出さ れた詳細設計報告書では，環境へのトリチウム放出に関し $\tau$, 設計のための放出量自主基準(暫定值)之放出量評価値 が報告されている(9)。前者の自主基隼值は，平常運転時の HTO放出について年間 $1 \mathrm{~g}-\mathrm{T} / \mathrm{yr}$ と設定されており，約 $370 \mathrm{TBq} / \mathrm{yr}$ に相当する。

一方，平常運転時の放出量の評価值は約 $110 \mathrm{TBq} / \mathrm{yr}$ で あると推定されており，放出量自主基準を満足している。 $110 \mathrm{TBq} / \mathrm{yr}$ のち，気体状トリチウムの放出量は約 100 $\mathrm{TBq} / \mathrm{yr}$ 上されており，残りは液体状卜リチゥムである。 これらの評価值は，カナダのCANDU炬やセラフィール ドの再処理施設に比べて，かなり少ない放出量といえる。 また, ITERの異常時におけるトリチウムの大気への放出 量限度に関する自主基準も設定されている( と, HTO放出の場合, 起こり得る異常に対しては $1 \mathrm{~g}-\mathrm{T} /$ 事象，起こり難い異常に対しては $50 \mathrm{~g}-\mathrm{T} /$ 事象，極めて起 こり難い異常に対しては $100 \mathrm{~g}-\mathrm{T} /$ 事象とされている。

\section{5.おわりに}

環境中には様々な起源のトリチウムが存在している。そ の最大のインベントリーは核実験によるものである。しか し，1981年以来，大気核実験は行われていないので，これ によるインベントリーは今後ますます減少すると考えられ る。医療や産業に伴うトリチウムは他の発生源に比べると 量的には限られている。将来は原子力利用に伴うトリチウ 么の割合が増加することが予想される。また，現在，工学 設計活動が進められているITERは大量のトリチウムイン ベントリーを有するものの，平常時の環境への放出量は他 の原子力施設に比へて，特別に大きくなることはないと考 えられる。

\section{一套考文献一}

(1) Okada, S., Momoshima, N. : Health Phys., 65, 595(1993).

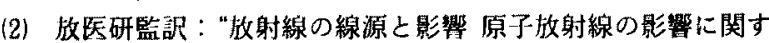
る[]連科学委只会の総会に対する1993年報告書 附属書付",

実業公報社，(1995）。

（3）科技庁原子力安全局編集：“放射線利用統計 1996 ”，日本了 イソトープ協会,（1997）.

(4) 日本原然湖：六ヶ所再処理・廃棄物事業所再処理事業指定申 請書，(1993年 3 月）.

(5) Bell., A.C., Caldwell-Nichols, C., Patel, B., Serio, L. : Fusion Technol., 28, 821(1995).

(6) Anderson, J. L., et al. : 15th Int. Conf. on Plasma Physics and Controlled Nuclear Fusion Research, Seville, Spain, Sept. 26-Oct. 1, 1994, IAEA, Vienna, Austria, Vol. 2, p.681 (1995).

(7) Rule, K., et al. : Fusion Technol., 28, 926(1995).

(8) IAEA: "Technical Basis for the ITER Interim Design Report, Cost Review and Safety Analysis", ITER EDA Documentation Ser., No.7, IAEA, Vienna, (1996).

（9）稻造輝雄：ITER設計報告 III.3ITERの安全性，ナラズマ・核 融合誌，73增刊, 160 (1997)

\section{III. トリチウムの生物影響および 生体内挙動}

\section{III-1 生物学的効果比(RBE)}

放射線医学総合咞究所 武 田 洋*

\section{1. 生物学的効果比 (RBE) とは}

放射線による影響は，生物組織・細胞内に吸収された放 射線のエネルギー量だけに依存するのではなく，電離密度 などにも関係する。電離密度は放射線の種類によって異な るため，同じェネルギーが吸収された場合です放射線の㮔 類により現れる影響の程度も異なることになる。すなわ ち，単位質量当たりに吸収されるエネルギ一量で表される 線量(吸収線量)に，放射線種の違いによる修正を行うこと によってはじめて生物影響と一定の関係が規定できる。こ の修正係数として，放射線生物学で実験的に得られる生物 学的効果比(RBE)がある。RBEは，基準放射線(X 線ある いは $\gamma$ 線)に対して問題とする放射線(ここではトリチウム $\beta$ 線)による生物効果の比であり，次式のように同じ生物 効果をもたらす時の 2 つの放射線の吸収線量の逆比として 表わされる。

$$
\begin{aligned}
& \text { ある生物効果を生じる時の } \\
& \text { 基準放射線の吸収線量 } \\
& \text { (RBE) }=\text { 基準放射線さ同じ生物效果を生じ }
\end{aligned}
$$

トリチウムによる生物影響の程度や特性を知るために, 様々な生物効果の指標(エンドポイント)を用いて，この RBEを求めることは，放射線生物学での基本的な研究手 法の一つである。

\footnotetext{
* Hiroshi TAKEDA, Natl. Inst. of Radiol. Sci.
} 


\section{2，RBEに関する研究の現状}

トリチウムに対するRBE值についてはここの10数年の 間に多くの報告がある。我が国でも核融合開発のための安 全研究として、トリチゥム生物影響についてのプロジェク 卜的研究が行われ，様々な指標での RBE 值が報告されて いる(1)(2)。その報告書の中で，国外加らの報告值む含めて RBEが取りまとめられている。動物個体お上び培養細胞 に対して，生物指標別によ゙のような RBEが報告されてい るかを第 III-1 表に示す。これによれば，HTOの RBE 值 は0.5 4.5の範囲であり, ${ }^{3} \mathrm{H}$-チミジンの RBE 值は0.6 5.9 範囲に及んでいる。

また，比較的最近報告されたトリチウムの RBE值をレ ビューしたものとして, Straume と Carsten の論文があ る(3)。彼らは，トリチウムによる発がん，遗伝子損傷，発生 巽常, 生殖腺障害の 4 つの指標に関するRBEをレビューし ている。この論文にまとめられた各生物指標に扔けるトリ チウムのRBEは以下の通りである。

\section{（1）発がんを指標とするトリチウムのRBE}

発がんに着目したRBE值については，動物個体での腫 瘍や白血病，または培養細胞でのトランスフォーメーショ ンの実験によるものである。いずれもHTOを使って行わ れた実験で，そのRBE值は $1 \sim 2$ の範囲である。

（2）遗伝子損伤を指標とするトリチウムの RBE

道伝子損傷に着目したRBE値については，上卜および 動物培金細胞での染色体異常や突然变異を指標にした HTOによる実験の結果，また一部有機結合型トリチゥム (Organically Bound Tritium: OBT)による実験の結果 がまとめられている。HTOによる実験はかなりの報告が

第 III-1表 樣々な指標でのトリチウムの RBE

\begin{tabular}{|c|c|c|c|c|}
\hline $\begin{array}{l}\text { トリチウム } \\
\text { の化学形 }\end{array}$ & $\begin{array}{l}\text { 実験に供 } \\
\text { した材料 }\end{array}$ & $\begin{array}{l}\text { 生物効槧 } \\
\text { の指標 }\end{array}$ & $\begin{array}{l}\text { 実験の } \\
\text { 件数 }^{+}\end{array}$ & $\begin{array}{l}\text { RBEの } \\
\text { 分布 }{ }^{\dagger+}\end{array}$ \\
\hline HTO & 培養細胞 & 細胞致死 & 17 & $1.0 \sim 3.0$ \\
\hline HTO & 培葿細胞 & 突然変翼 & 6 & $1.3 \sim 2.9$ \\
\hline HTO & 培養細胞 & 染色体障害 & 4 & $1.2 \sim 4.5$ \\
\hline HTO & 培美細胞 & 発がん & 3 & $0.5 \sim 1.8$ \\
\hline HTO & 培養細胞 & 初期発生異常 & 6 & $1.1 \sim 1.7$ \\
\hline HTO & 動物個体 & 個体致死 & 4 & $1.0 \sim 2.1$ \\
\hline HTO & 動物個体 & 細胞減少 & 3 & $1.0 \sim 2.1$ \\
\hline HTO & 動物個体 & 造血障害 & 4 & $0.9 \sim 2.2$ \\
\hline HTO & 動物個体 & 染岜体異常 & 4 & $1.0 \sim 2.7$ \\
\hline HTO & 動物個体 & 生殖腺障害 & 3 & $1.1 \sim 2.9$ \\
\hline HTO & 動物個体 & 胎仔の奇形 & 1 & $1.8 \sim 2.6$ \\
\hline HTO & 動物個体 & 突然変異 & 4 & $0.7 \sim 2.2$ \\
\hline HTO & 動物個体 & 細胞致死 & 2 & $1.0 \sim 1.6$ \\
\hline${ }^{3} \mathrm{H}-千$ ミシシン & 培盖細胞 & 細胞致死 & 6 & $0.9 \sim 2.3$ \\
\hline${ }^{3} \mathrm{H}-千$ ミ ジン & 培養細胞 & DNA 鎖切断 & 3 & $1.0 \sim 1.5$ \\
\hline${ }^{3} \mathrm{H}-$ チ シシン & 培莨細胞 & 染色体異常 & 1 & $0.6 \sim 1.0$ \\
\hline${ }^{3} \mathrm{H}-$ 路ジン & 培盖細胞 & 染然変異 & 2 & $3.0 \sim 5.9$ \\
\hline
\end{tabular}

†著者加確認できた実験件数であり，RBEの分布における頻度の目安 として示した。

"図示されたあのから筆者が読み取った値も含んでいる。
あり，X線を基準放射線とした場合の RBE 值は $1 \sim 2$ の 範囲に，また $\gamma$ 線を基準放射線とした場合の RBE 值は 2 〜 3 の範囲に区別できるとしている。一方，OBT の RBE については，アミノ酸とチミジンでの実駼結果があるが, ${ }^{3} \mathrm{H}-$ ア /酸のRBE はHTO の結果と差がなく, ${ }^{3} \mathrm{H}-$ チミ ジンのRBE はHTOの場合より 2 倍程度高くなるとしてい る。

（3）発生異常を指標とするトリチウムの RBE

娃娠時の被ばくによる発生異常を指標としてトリチゥム $\beta$ 線のRBEを求めた実験は少ないが，報告されている動物 個体を用いたRBE値は，1２.6の範囲にあるとしている。

(4) 生殖腺障害を指標とするトリチウムの RBE

生殖腺障害に着目したRBE 値については，HTOあるい

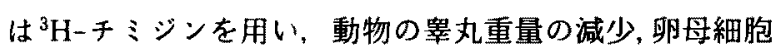
や精原細胞の致死，さらに魚の生殖細胞への影響を指標之 した実験結果がまとめられている。これによれば，HTO の RBE 值は1.4 2.9の範囲であり，また ${ }^{3} \mathrm{H}-$ チジンの RBE 值は1.6〜3.7の範囲にある。

\section{RBEに関する問題点}

報告されているトリチウムのRBEは 1 以下加ら 6 程度 のかなり広い範囲にわたっている。このような差異が見ら れる要因よして、次のような点が考えられている。

\section{（1） 実験に用いる生物材料の差}

細胞致死あるいは発がんといった特定の生物効果指標を 用いた実験であってあ，使用する動物種や細胞系によって 得られるRBEの值が大きく異なることがある。その原因 としては, 生物材料によってその構造(標的のサイズ)や機 能(修復能力など)が違うために，2 種の放射線(トリチウ 厶と基準放射線)に対して異なる放射線感受性を示すため と推測される。

（2）生物勃果の指標(エンドポイント)の違い

たとえ同じ生物材料を使用したときでる，調べる影響の 指標が異なる場合には，RBEの值も異なることが知られ ている。岡田ら ${ }^{(4)}$ や上野ら ${ }^{(5)}$ は，マウスの L5178Y 細胞 を用い，細胞死や突然変異誘発などを生物勃果指標として 求めたRBEが，それぞれの指標によって異なることを明 らかにしている。このように, 特定細胞でも指標によって RBEが異なる原因として，岡田ら (4) は, 各生物効果指標 の標的のサイズに俄存する可能性を示唆している。一方, Bond ら ${ }^{(6)}$ は, $\gamma$ 線, X線およびトリチゥム $\beta$ 線について, 標的のサイズが変化した場合の RBE を微視的吸収線量の 算定により導いて，第田-2 表に示すように，標的のサイ ズが小さくなるはどトリチウムのRBEは大きくなると理 論的な解析を行っている。

（3）基準放射線の違い

$\mathrm{RBE}$ を求める場合の基準放射線として，一般に250 $\mathrm{kVpX}$ 線あるいは ${ }^{60} \mathrm{Co} \gamma$ 線が用いられる。第 III -2 表に示 したトリチウムの $\mathrm{RBE}$ と標的のサイズの関係から明らか 
第 III-2 表 標的のサイズによるRBEの変化

\begin{tabular}{lcccc}
\hline & $\begin{array}{c}\text { 標的の直径 } \\
(\mu \mathrm{m})\end{array}$ & ${ }^{60} \mathrm{Co} \gamma$ 線 & $\begin{array}{c}250 \mathrm{kVpX} \text { X 線 } \\
\mathrm{HVL}\end{array}$ & $\begin{array}{l}1.8 \mathrm{~mm} \mathrm{Cu} \\
\beta \text { 線 }\end{array}$ \\
\hline $250 \mathrm{kVpX}$ X線 & 1 & 0.4 & 1 & 1.5 \\
を基準とした & 3 & 0.4 & 1 & 1.1 \\
場合 & 5 & 0.4 & 1 & 1.0 \\
\hline${ }^{60} \mathrm{Co} \gamma$ 線を & 1 & 1 & 2.5 & 3.8 \\
基準とした & 3 & 1 & 2.5 & 3.3 \\
場合 & 5 & 1 & 2.5 & 2.5 \\
\hline
\end{tabular}

なように，標的のサイズが同じであってむトリチウムの $\mathrm{RBE}$ は $250 \mathrm{kVpX}$ 線を基準とした場合と ${ }^{60} \mathrm{Co} \gamma$ 線を基準 とした場合で異なることが理論的に解析されている。すな わち，2つの基準放射線の間で標的内へ与えるエネルギー 量(吸収線量)に差があり，その差から $250 \mathrm{kVpX}$ 線は60 Co $\gamma$ 線より 2.5 倍程度高い生物効果を与えると理論的に予 測される。

前述の Straume と Carstenによる RBEをレビューした 論文 ${ }^{(3)}$ のなかで，X線 $(180 〜 250 \mathrm{kVp})$ を基準放射線として 得られた RBE 值(12件) と ${ }^{137} \mathrm{Cs}$ あるいは ${ }^{60} \mathrm{Cor}$ 線を基準放 射線として得られた RBE值(21件)に分け，両者を比較し ている。第 III-1 図にX 線を基準放射線とした場合，そし て第 III-2 図に $\gamma$ 線を基準放射線とした場合の結果を示し ている。なお、これらの結果はいずれすHTOのRBEを調 べた実験の結果である。

これによれば，X線と $\gamma$ 線のどちらの放射線を基準とし た場合にも, HTOの RBE は 1 3.5 の範囲にあるが，X 線を基準放射線とした場合の RBE は $1 \sim 2$ に高い分布を 示し，全体を算術平均した值は1.8となり，一方， $\gamma$ 線を 基準放射線とした場合の RBEは $2 \sim 3$ のところに高い分

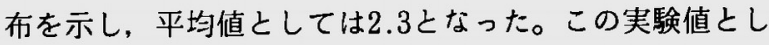

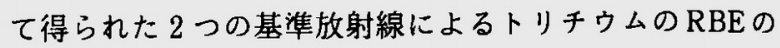
結果は, Bond $ら^{(6)}$ によって理論的な微視的線量評価に 基づいて得られた RBEともよく一致しているように思え る。

このように, $\mathrm{RBE}$ を求めるための基準放射線を $\mathrm{X}$ 線と $\gamma$ 線のどちらにするかは大事な問題である。ICRPでもこの 問題は議論されているようであるが(7), 現在のところ決定 はなされていない。

\section{(4) 線量率の差}

放射線，特に低LET(線エネルギー付与)放射線被ばく によって分子レベル, あるいは細胞レベルに発生した変化 は, そのまま固定されるのではなく, 修復され, あとの状 態に戻る場合が多い。単位時間当りの線量が低く, 線量が 分割して与えられたほうが, 修復や回復の起こる機会が増 え, 影響(臨床的)として現れる可能性は小さくなる。これ は線量率効果と呼ばれ, 受けた総線量が同じ場合には, 低 線量率ほど影響の程度は小さくなる現象である。この線量 率効果の現象がトリチウムの RBEを変動させるとすれば， それはトリチゥムと基準放射線(X線や $\gamma$ 線)に対して異な る線量率効果を示すためと考えられる。

実際に, トリチウムの RBEが低線量・低線量率で大きく なるという実験報告は少なくない。Hall ら ${ }^{(8)}$ は, Hela 細 胞の成長抑制之致死効果が，線量率を $32 \mathrm{cGy} / \mathrm{h}$ から 1 $\mathrm{cGy} / \mathrm{h}$ に滅少したとき， $\gamma$ 線に対するトリチウムの $\mathrm{RBE}$ が 2 倍に増加することを示している。トリチウム $\beta$ 線は 基準放射線の $\gamma$ 線に比べて LET が高いので，両放射線の 線量率を下げると, $\gamma$ 線の方が効率よく損傷の修復が起こ り, 結果としてトリチウムの RBEが大きくなると予想さ れる。

また, Sinclair ${ }^{(9)}$ は，一般に基準放射線として用いられ ている $250 \mathrm{kVp} \mathrm{X}$ 線と ${ }^{60} \mathrm{Co} \gamma$ 線による影響をいくつかの指

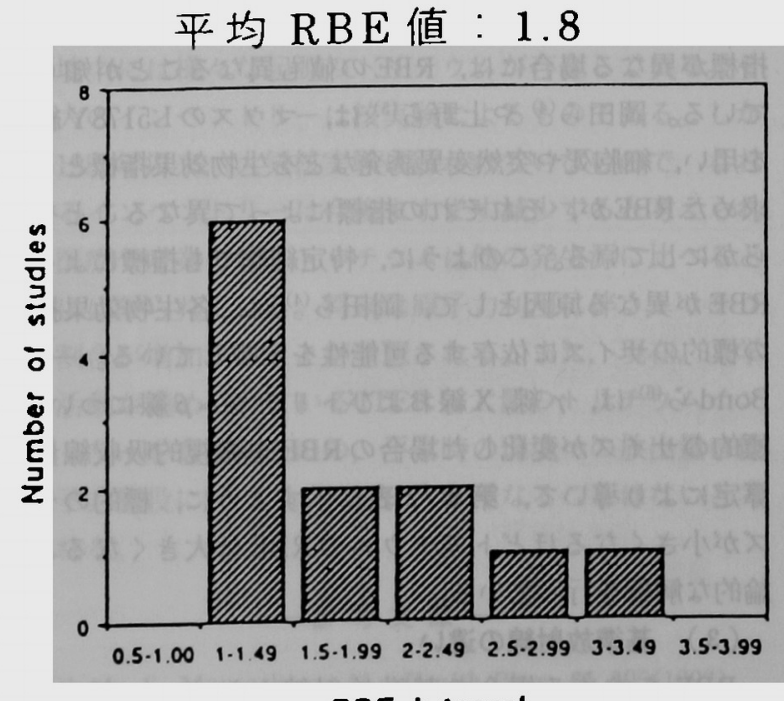

RBE Interval

第 III-1 図 $\mathrm{X}$ 線を基準放射線として得られた $\mathrm{RBE}$ 値 (Straume \& Carstenの論文 ${ }^{(3)} よ り$ 転写)
平均 $\mathrm{RBE}$ 值 : 2.3

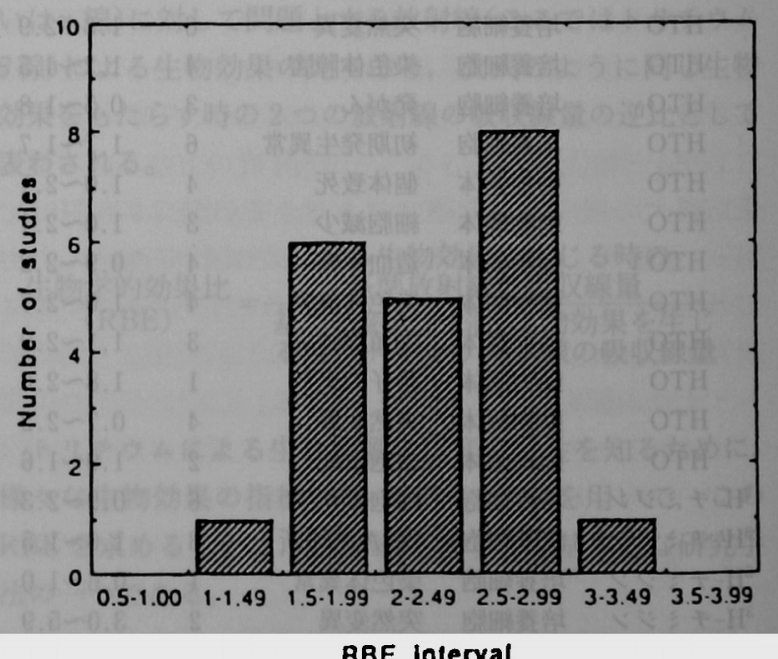

RBE interval

第 III-2 図 $\gamma$ 線を基準放射線として得られたRBE 値 (Straume \& Carsten の論文 ${ }^{(3)}$ より転写) 
標で比較した結果として，X線に対する ${ }^{60} \mathrm{Co} \gamma$ 線の RBE は1より小さく，またその值は線量率によって変化し，低 線量率ほど小さくなると報告している。この結果は, トリ 千ウムの RBEの低線量域での增加が, 基準放射線として $\mathrm{X}$ 線より $\gamma$ 線を用いたとさに起こる可能性が高いことを 示している。

このように，RBEはあくまで基準放射線との比較で求 められる值であり、トリチウムの生物効果が低線量になる に还い大きくなるということではない。

(5) トリチウムの化学形の逵い

トリチウムの RBEは，その化学形によって異なる場合

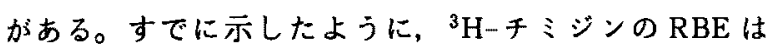
HTOより高い傾向が見られ，Straume ら ${ }^{(3)}$ はその差を約 2 倍と推定している。

このようにRBEがトリチウムの化学形によって異なる 原因としては，生体高分子に取り込まれたトりチウム (OBT)の壊変(トランスミューテーション)効果と,この OBTによる線量の不均一性によるという可能性がある。 壊変勃果とは，トリチウムが $\beta$ 崩壊してへリウムに変わる ことによって分子的变化を起こし，それが存在する部位に よっては何らかの生物効果をむたらすかもしれないという ことである。しかし，Feinendegen ら ${ }^{(10)}$ は，この効果は 特殊な条件下を除けば，細胞がもっている修復作用によ り， $\beta$ 線による効果以上には見い出すことができないと結 論している。またこのトリチウム壊変に伴ってリコイルエ ネルギー(最大 $3 \mathrm{eV})$ が発生するが，これも分子内の化学 結合を切る活どのエネルギーではないと考えられている。

一方, OBTに上る線量の不均一性については，核酸 (DNA)の前駆体である ${ }^{3} \mathrm{H}-$ チミジン等では十分考えられ ることで，むしろRBEを導くための線量算定法か問題と なる。培養細胞を用いた実験です，RBEを求めるための 線量算定は, 多くの場合卜リチウムが細胞内に均等に分布 しているものと仮定している。培養細胞では, ${ }^{3} \mathrm{H}-$ チミジ ンを生物効果の標的と考えられる細胞核内一選択的に取り 込むため，その生物効果は均等分布を仮定した線量加ら予 測されるより大きく，結果として高いRBEとなる。

以上のように，実験的に得られるRBEには様々な変動 要因を有している。このRBEの変動要因は，放射線生物 学ではそれ自体が研究対象之なるが，放射線防護の目的で 使用する係数(線質係数あるいは放射線荷重係数) と関連づ ける場合には，問題となる。

\section{一至考文献一}

（1）澤田昭三：“トリチゥム筫料集一 $1988 ” ，$ 核融合特別研究総合 総括班事業, 243 (1988).

(2) 䚄田昭三, 岡田重文: “核融合研究者の為のトリチウム安全取 扱いの目安一1990"，143(1990).

(3) Straume, T., Carsten, A. L. : Health Phys., 65, 657 (1993).

(4) Okada, S., et al. : Radiat. Prot. Dosim., 16, 137(1986).

(5) Ueno, A. M., et al. : Radiat. Res., 91, 447 (1982).
(6) Bond, V. P. : Health Phys., 34, 433 (1978).

（7）松平寬通：“トリ手ウム資料集一1988”，核蛬合特別研究総合 総括班事業, 236 (1988).

(8) Hall, E. J., et al. : Br. J. Radiol., 40, 704(1967).

(9) Sinclair, W. K. : Radiat. Res., 16, 384(1962).

(10) Feinendegen, L. E., Bond, V. P. : "Tritium", (Moghissi, A. A., Carter, M. W., Eds.), Messenger Graphics, Phoenix, 221 (1973).

\section{III-2 生体内挙動とモデル}

京都大学原子吙実験所 齊 藤 眞 弘*

トリチウムの人体内での化学的ふるまいを研究すること は, 人体内での水素のふるまいを研究することと同じこと でおる。そこで, マウス, ラット, ウサギなどをモデル動 物として，生体内でのトリチウムのふるまいを調べる研究 が多くの研究者によって行われ，人体内でのトリチウムの ふるまいがモデル化(体内動態モデル)されている。

\section{1. 生体内トリチウムの化学形}

ヒトを含め、哺乳類のからだの中には重さにしておよそ 70\%の水が含まれている。そのため，人体に取り込まれた HTOの大部分は水の形で残留する。このように, 水の形 をとっているトリチウムは自由水型トリチウム $(F W T)$ と 呼ばれる。自由水型トリチウムは, 全身の水(体内水とい う)の中に一様な比放射能をもって分布する。

地球環境中で，ほとんどの植物は水と炭酸ガスを材料に 様々な有機物を合成(光合成)する。その際，環境中の HTOに含まれるトリチゥム原子はさまざまな有機化合物 に取り込まれ炭素原子や窒素原子に有機的に結合して OBT となる。OBT は食物連鎖を介してヒトの体内に取り 込まれる。

OBT はNA やタンパク質などに結合している場合に は，細胞内で細胞核など生体の機能に重要な役割を果たす 部分に局在して残留するために，それら細胞内局在の効果 あ考虑して線量評価を行う必要がある(1)(2)。

\section{HTOとして取り込まれたトリチウムの 体内挙動}

HTOから生体構成分子へのトリチウムの転入には次の

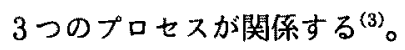

(1) 直接的な化学交換反応：生体ポリマー分子上の化 学的に不安定なプロトンとトリチウム原子との交換反 応。

（2）生化学的な反応による，炭素に結合した位置へのト リチゥム取込み。

(3) HTOの水和：生体内で生体を構成する分子に強 く引きつけられ，その分子と行動をともにするような 水分子のことを水和水(hydrated water) と呼ぶ。水

* Masahiro SAITO, Res. Reactor Inst., Kyoto Univ. 
利水は生体高分子の構造を生体队で安定に保ち, 必要 な機能を発現するためにかかせない。HTOはDNAな ど生体高分子の水和層(hydration layer)にも入り込 むが，このトリチウムは自由水中のトリチウムに比べ

て動きが遅く，生体内で長く残留する。

HTOを慢性的に摄取するようなことが起こるのは，作 業環境の空気中に恒常的にトリチウム水蒸気が存在する場 合と, 飲食物中の水分にHTOが入っている場合である。 空気中のトリチゥム水蒸気による内部被ばく時は呼吸器か らの吸入と皮䖉からの吸収がトリチウム体内取込みの主な 経路となる。

体内自由水の供給源として, 食物が体内でエネルギーに 変ることによって生ずる水があり，「体内酸化水(代謝水)」 と呼ばれるが，体内酸化は食物を食べた後，ただちに行わ れるので, トリチゥム体内動態をモデル化する際には, こ の体内酸化水も含めて自由水の取込み量とされる。

HTOを一定の割合で飲んだようなとき, 組織中の生体 高分子は徐々にトリチゥムで標識され，OBT の比放射能 は一定のレベル(平衡レベル)に達する。この平衡レベルの 程度と平衡に達する時間は, 標識される高分子の種類およ びその組織中での入れ替わりの速さ(ターンオーバー率)で 決まる。

HTOを飲ませて動物体内での OBT への变換過程や生体 高分子成分での残り具合を調べる実験は，マウス,ラット， 豚, 子牛等を使って行われてきた。トリチウムによる内部 被ばく線量は体内にトリチウムか残っている時間で決まる が,この時間は体重と逆の関係にある。つまり，大きな動 物ほど身体に入ったトリチウムは出ていきにくいというこ とである。HTOを飲んだ時, トリチウムの半分が体外に 出て行く時間(すなわち生物的半減期)はマゥスで約 2.5 日(")，ラットで約 3.5 日 $^{(5)}$, 豚では約 4 日 $^{(6)}$ である。また ヒトでは約10日である ${ }^{(7)(8)}$ 。

体队の自由水成分のトリチウムについては，あらまし上 のような生物的半減期で咸少するが, すう少し詳しく, 長 い時間にわたって調へててると，HTO摄取停止後の体内 濃度は, 組織によって異なる経過をとって減少することが わかる。どの組織においても自由水成分中のトリチウムは ほぼ同じ牛物的半減期で減少するが, OBT の残存曲線は 組織によって違いがあり，かつトリチウムが結合した牛体 高分子の種類によって，さきに述べた代謝回転率の咯いが あるためである。

その具体的な例として，第 III-3 図にHTO投与マウスで の体队残存曲線を示す ${ }^{(9)}$ 。この実験では，仔マウスが生ま れた宜後から離乳まで, 母マウスにHTOを飲ませ続け離 乳後の仔マウスの体队に残っているトリチウム量を長期間 (40週)追いかけている。離乳後 1 力月ほどで総トリチウム 濃度は脂肪組織を除くすべての組織で投与直後の 1 ～2\% に減るが、残っているトリチウムの量は組織によって大き く界なる。最もトリチゥム浱度が高いのは脳であった。こ

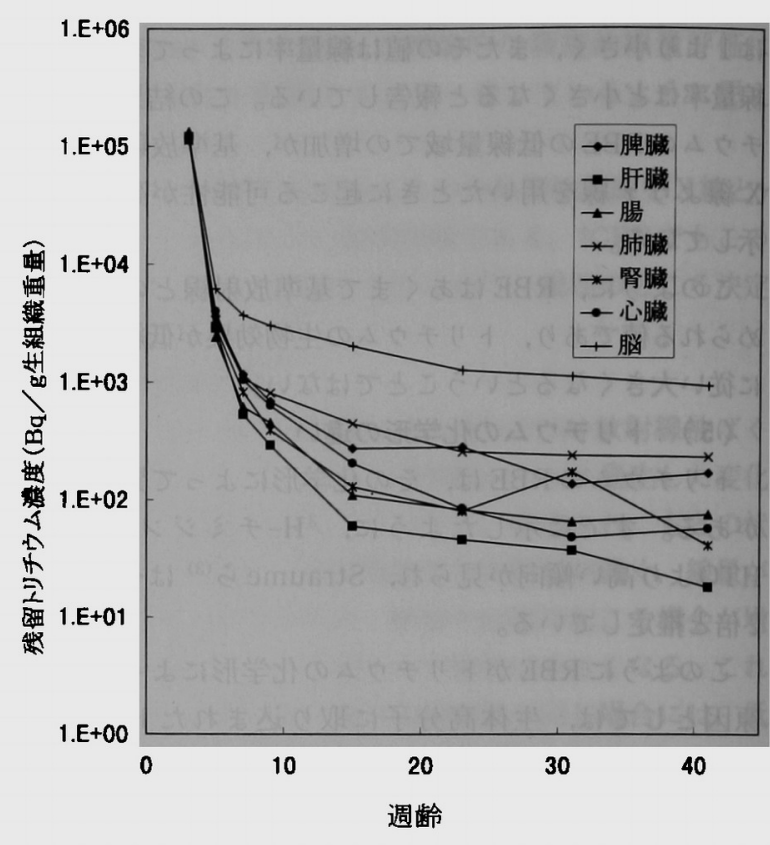

第 III-3 図 飲料水としてHTOを与えられた母マウスにより 離乳まで育てられた仔マウス体内の残留トリチ ウム濃度 ${ }^{(9)}$

のように，量は少ないけれどむ，長く体内に残るトリチウ ムがあるということは，水として母マウスが飲んだトリチ ウムがどこかで有機結合型のトリチウムに变化することを 意味している。

では，どのような生体成分に変換したトリチウムが長く 残るのか。これを調べるために，組織中トリチウムを酸可 溶成分, 脂質, 核酸, 蛋白質の各成分に分離することが試 みられ，脳の成分である脂質(リピド)にトリチウムが特に 有効に取り込まれ，長く残留することが明らかになっ た(10)。

\section{3. 母体から胎児または乳児への移行}

トリチゥムの母体から胎児への移行に関しては，ヒトに ついてのデータがない。そのため, 動物実験の結果から推 定することになる。動物実験は，その結果をそのままヒト にあてはめることはできないが，ヒトについて作られたモ デルの信用性を確かめるためには大変役に立つ。

これまで奸嫬母体に対するトリチゥム投与実験はHTO および ${ }^{3} \mathrm{H}$-チミジンで行われている。マウスの場合, ${ }^{3} \mathrm{H}-$ チミジンを母マウスに飲ませた時は20４0\%のトリチウム が胎児体内のOBTに变換される(10)。一方，HTOについ

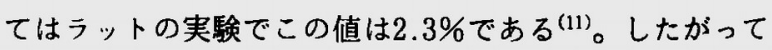
母体-胎児の系では, OBT と HTOでの胎児OBTへの取込 み効率は約10倍違う。興味あるのは、ラットでの実験によ るとHTO投与後の新生児組織内自由水型卜リチウムが母 体に比べて長い生物的半隇期を持っていることである ${ }^{(2)}$ 。 これは新生児ではHTOからOBTへの変換率が高く，半減 
期の長いOBT成分として蓄皘されたトリチウムが徐々に 自由水成分に変換されるためであると考えられる。

母体は通常, 飲食物中からトリチウムを摄取するのでこ の母体-母乳釈児の系はひとつの食物連鎖系之みることか できる。牛乳は七トにとって重要な栄養源であるが，乳牛 や豚を使った大規模な動物実験がョーロッパを中心に行わ れだ ${ }^{(13)(14)}$ 。飲み水中のトリチウムがミルク中のOBTに変 換される割合が最む高かったのは、 ミルク中の固形成分で あった。ミルク中固形成分のラクトースでは，その構成水 素原子のうち $48 \%$ が摂取した水に由来するためである。

\section{4. トリチウムの体外排泄を促進する方法}

トリチゥムの体外排泄を促進することは，被ばく線量を 堿らすために重要である。体内のOBT の代謝回転率を高 わることは難しいが, 自由水トリチウムについては，体内 自由水の代謝回転率を人為的に大きくすることによってそ の体外排泄をある程度促進することができる。実際，大量 の水を飲むことによって体内のトリチウム濃度を下げる試 みがいくつかの被ばく事故の際に行われた ${ }^{(15)(16)}$ 。水分摂 取や利尿郕によるトリチゥム排泄の促進効果は一政らに よって，ラットを用いた実験で系統的に調べられてお り(1゙，特にサッカリンやビールが副作用なしに尿中およ び組織中のトリチゥム濃度を減少させるのに有効であるこ とがわかっている。トリチウムを欺み込んだり，吸い込ん だりした時は，ビール，ジュース，清涼飲料水のたぐいを ひたすら飲むべしということである。

\section{5. トリチゥムの体内動態モテル}

OBT を含めたトリチウムによる内部被ばく線量を評価 するためには，身体全体をひとつのブラックボックスとし て考え，その中に含まれる OBTや自由水型のトリチウム (FWT)をいくつかの特徽的な挙動をするグループに分け， それぞれのグループ(コンパートメントという)をひとまと めにして考元る方法が採られる。

これまでにトリチウム体内動態のモデルとしていくつか のコンパートメントモデル(18) (22) 功提唱されている。も デルの有用性は，そのモデルで使われる水素代謝について のパラメータがどのくらいの確かさで対象集団を代表でき るかということと，個々の内部被ばくのケースについての パラメー夕修正の签易さで決まる。この上うなことを考え て作られたトリチウム体内動態モデルとして，体内水素収 支に基づいた 3 コンパートメントモデル(Modified three compartment model : MTCモデル) ${ }^{(18)}$ がある。

MTCモデルを第 III-4 图に示す。体内TFWT（体内自由 水)コンパートメントをTFW，第 $1 の \mathrm{TBWH}$ (組織結合 水)コンパートメントをTBW-1, 第 2 のTBWH コンパー トメントをTBW-2 と表してある。このモデルでは, 飲食 物中のFWHはすへて直接体内自由水コンパートメントに 取り込まれる。一方, 飲食物中の有機結合型水素 $(\mathrm{OBH})$

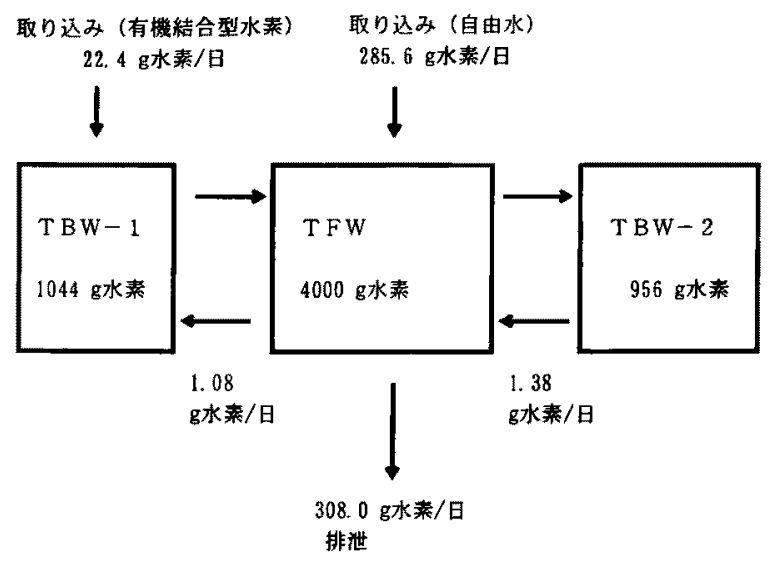

$\mathrm{g}$ 水素：自由水または有機結合型水素として含まれる水素原子の量 $(\mathrm{g})$

第 III-4㘡 標準人についてのMTCモデル゙18

の一部は直接，OBH として OBH-1コンパートメントに取 り込まれ，一部は体内取込み後，直ちに酸化され自由水コ ンパートメントTFWに取り込まれる。

\section{6. 結語}

核融合の然料となるトリチウムの安全性研究は，地球環 境や人体内での水のふるまいを研究することに通じる。人 体に取り込まれたトリチゥムがどのようにふるまい，どの ような場所に長期にわたって残るかを調へ，体内での水素 のふるまいをモデル化することにより，内部被ばく線量の 評価をすることができる。

\section{一参考文献一}

(1) Saito, M., et al.: Health Phys.. 48, 465 (1985).

(2) Saito, M., et al.: Health Phys., 56, 869 (1989).

(3) Mathur-De Vre, R., Binet, J. : Prog. Biophys. Molec. Biol., 43, 161 (1984).

(4) Saito, M., Ishida, M. : Radiat. Prot. Dosim., 16, 131 (1986).

(5) Takeda, H. : NIRS-M-41, 187 (1982).

(6) Kirchmann, R., Charles, P., Van Bruwaene, R., Remy, J., Koch, G., Van den Hoek, J. : Curr. Top. Radiat. Res., 12, 291 (1977).

（7）上野陽里：昭和62年度文部省科学研究費補助金研究成果報告 書「トリチゥム資料集・1988」, 349 (1988)。

(8) 高田和夫：昭和62年度文部省科学研究費補助金研究成果報告 書「トリチゥム資料集・1988」, 352 (1988)

(9) Saito, M., Ishida, M. R. : Radiat. Prot. Dosim., 16, 131 (1986).

(10) Saito, M., Streffer, C., Molls, M. : Radiat. Res., 95, 273 (1983).

(11) 武田 洋: 私 信.

(17) Moskalev, Y. I. : "Tritium", (A. Moghissi, M. Carter, eds.), Messenger Graphics, Phoenix, 241 (1973).

(13) Van den Hoek, J., Ten Have, M. H., Gerber, G. B. : Health Phys., 44. 127 (1983).

(14) Van den Hoek, J., Ten Have, M. H., Gerber, G. B., Krchman, R. : Radiat. Res., 103, 105 (1985).

(15) Akaishi, J. : Proc. 2nd Workshop on Tritium Radiobiology 
and Health Physics, NIRS-M-41, 285 (1982).

(16) Sanders, S. M., Reinigj, W. C. : Proc. Symp. for the Diagnosis and treatment of Deposited Radionuclides (Kornberg, $\mathrm{H}$ A., Norwood, W. D., eds.), Monographs on Nuclear Medicine and Biology, No.2, p.534, Excerpta Medica, Amsterdam (1968).

(17) Ichimasa, Y., Akita, Y. : NIRS-M-41, 205 (1982).

(18) Saito, M. : Radiat. Prot. Dosim., 42, 17 (1992).

(19) Snyder, W. S., Fish, B. R., Bernard, S. R., Ford, M. R., Muir, J. R. : Phys. Med. Biol., 130, 547 (1968).

(20) ICRP : ICRP Publ. 56, Pergamon Press, Oxford, (1990).

(21) NCRP : NCRP Rep. No.63, Tritium and Other Radionuclides Labelled Organic Compounds Incorporated into Genetic Material. (1979).

(22) Etnier, E. L., Travis, C. C., Hetrick, D. M. : Radiat. Res., 100 , 487 (1984).

\section{III-3 ICRPの考え方と線量係数}

放射線医学総合研究所 武田 洋

\section{1.トリチウムの線量評価に関するICRPの考え方}

現行の我が国の放射線障害の防止に関する法令は, ICRPの1977年勧告(1)を取り込んで，1989年に改正された あのである。ICRPはこの勧告で，しきい値がないとみな さ㧈る確率的影響の確率を容羿できるレベルまで制限する ために, 線量限度(職業人に対して $50 \mathrm{mSv} / \mathrm{yr}$, 公衆に対し て $1 \mathrm{mSv} / \mathrm{yr}$ )を設定している。この線量制限值として ICRP は，生物影響と一定の相関を持つ量として定義した 線量当量(あるいは実效線量当量)を用いている。線量当量 は, 単位質量当たりに吸収される放射線のエネルギー量 (吸収線量)を放射線の種類やエネルギーによって生物効果 が異なることを考慮し，ICRPが選定した線質係数(Q)で 修正した量である。他の放射線と比較してトリチゥムの生 物影響評価や線量評価を行う場合に，最む重要となるのが この線質係数である。

1977年のICRP勧告では，この線質係数を水中における 衝突阻止能 $\left(L_{\infty}\right)$ の関数として定義しており,トリチウム $\beta$ 線に対する線質係数は 1 としている。線質係数の決定に 当たりICRPは，与えられた放射線によるいろいろな生物 指標での生物学的効果比(RBE)を慎重に判断したとしな がらも，RBEは種々の条件で変動し放射線防護の目的に は不適であるため, 普遍的な物理量である $L \ldots$ との関数と して一義的に定義したものである。この定義においても， トリチウム $\beta$ 線の線質係数は 1 ではなく 2 に近いのではと いう考えがあった。しかし，ICRPは過去に線エネルギー 付与 (LET)の関数として線質係数を定義し1.7としてい た (2)が，当時の生物影響の㬰験結果を考虑し 1 に修正し た (3) 経緯がある。

ICRP は1990年の新勧告(4)で，1977年勧告以来の放射線 防護体系や線量限度值の变更など，大幅な改訂を行い，線 梊係数についても見直しを行った。この新衔告で，線所係

数は吸収線量を荷重する係数として新たに放射線荷重係数 と定義され，中性子等では低線量における確率的影響に関 するRBEを考虑して変更が行われた。しかし、トリチウ 厶を含む低LET放射線(X 線や $\gamma$ 線)に対しては以前之同 様すべて1己された。すなわち，ICRP は放射線防蓝上卜 リチゥム $\beta$ 線が $X$ 線や $\gamma$ 線之区別して特別考虑の必要な放 射線であるとは考えていない。この理由としては,トリチ ウム被ばくのような低LET放射線の低線量率被ばくに対 しては, 現行の線量限度の中で十分安全性が確保できると ICRPが考えているためと推測できる。

\section{ICRPが提示したトリチウムに対する線量係数}

ICRP は1977年勧告に基づき，放射性核種の攝取による 内部被ばくを線量限度以下に抑えるための目安となる補助 限度を提示している(5)。この補助限度としては，1 年間あ たりの放射性物質への被ばくによる預託実効線量当量が線 量限度に等しくなる経口および吸入摄取量である年搷取限 度(ALI)，あるいは呼気として吸入することによって被ば くし，その線量が線量限度となる空気中の放射能濃度であ る誘導空気中濃度 (DAC)がある。

これらの補助限度は, 当然ながら基本限度である線量限 度に支配され，1977年勧告から1990年勧告での職業人に対 する線量限度値の変更 $(50 \mathrm{mSv} / \mathrm{yr}$ から 5 年間平均値とし て $20 \mathrm{mSv} / \mathrm{yr}$ 年へ)に伴い, トリチゥム(HTO)の年摂取限 度では， $3 \times 10^{9} \mathrm{~Bq}^{(5)}$ から $1 \times 10^{9} \mathrm{~Bq}^{(6)}$ へと変更されること になった。このように，線量限度の見直しによって変更を 余儀なくされるALIやDACとは別に，むしろこれらの補 助限度の算定根拠となる「線量係数」を最近のICRPレポー トでは提示している。線量係数とは，単位摄取量 $(1 \mathrm{~Bq})$ 当 たりの実効線量当量で, 必要パラメータを与えられた体内 動態モデルによって算定される。ICRPがはじめて線量係 数を提示したのはPubl.56(7) であるが，これは一般公衆を 対象にして設定されたもので，当初は公衆へのALIを設 定することが考えられていた。しかし，公采に対してはむ しろALIよりる線量係数を設定しておく方が実用上便利 であるという考えで変更されたそうである(日)。Publ.56で は，公衆の構成員として 3 ヶ月齢，1歳，5歳，10歳，15歳 および成人に対する線量係数を設定している。この線量係 数を算定するため，ICRP はPubl. 30 (5) の刊行以後に導か れた新しい体内動態モデルを導入した。トリチウムの場合 これまで，体内では体液成分だけに存在し，半減期10日で 排泄するというモデルであった(5)が，上り現実的なモデ ルとして体液成分だけでなく組織有機成分にもトリチウム は存在し，各成分の半減期は成人で10日と40日(半減期は 年龄群別にそれぞれ異なる)とする体内動態モデルを採用 した(7)。また, 新しいモデルでは被ばく形態としてHTO だけでなくOBT す対象としている。

ICRPは，この公衆を対象とする線量係数を提示した 後, 1990年勧告 ${ }^{(4)}$ で新しい組織荷重係数を取り入れ，ま 
第 III-3 表一般公采に対して設定された線量係数(ICRP Publ. $72 よ り)$

\begin{tabular}{|c|c|c|c|c|c|c|}
\hline \multirow{3}{*}{ 年 蹸 } & \multicolumn{6}{|c|}{ 線量係数 $(\mathrm{Sv} / \mathrm{Bq})$} \\
\hline & \multicolumn{2}{|c|}{ 経口摄取 } & \multicolumn{4}{|c|}{ 吸入揁取(可溶性またはガス状のトリチゥム)"1 } \\
\hline & HTO & OBT & $\mathrm{HTO}^{\dagger 2}$ & OBT & $\mathrm{HT}^{\dagger 3}$ & $\mathrm{CH}_{3} \mathrm{~T}$ \\
\hline 3 ヶ月龄 & $6.4 \mathrm{E}-11$ & $1.2 \mathrm{E}-10$ & $6.4 \mathrm{E}-11$ & $1.1 \mathrm{E}-10$ & $6.4 \mathrm{E}-15$ & $6.4 \mathrm{E}-13$ \\
\hline 1 藏 & $4.8 \mathrm{E}-11$ & $1.2 \mathrm{E}-10$ & $4.8 \mathrm{E}-11$ & $1.1 E-10$ & $4.8 \mathrm{E}-15$ & $4.8 \mathrm{E}-13$ \\
\hline 5 歳 & $3.1 \mathrm{E}-11$ & $7.3 E-11$ & $3.1 \mathrm{E}-11$ & $7.0 \mathrm{E}-11$ & $3.1 \mathrm{E}-15$ & $3.1 \mathrm{E}-13$ \\
\hline 10 藏 & $2.3 \mathrm{E}-11$ & $5.7 \mathrm{E}-11$ & $2.3 \mathrm{E}-11$ & $5.5 \mathrm{E}-11$ & $2,3 \mathrm{E}-15$ & $2.3 E-13$ \\
\hline 15歳 & $1.8 \mathrm{E}-11$ & $4.2 \mathrm{E}-11$ & $1.8 \mathrm{E}-11$ & $4.1 \mathrm{E}-11$ & $1.8 \mathrm{E}-15$ & $1.8 \mathrm{E}-13$ \\
\hline 成人 & $1.8 \mathrm{E}-11$ & $4.2 \mathrm{E}-11$ & $1.8 \mathrm{E}-11$ & $4.1 \mathrm{E}-11$ & $1.8 \mathrm{E}-15$ & $1.8 \mathrm{E}-13$ \\
\hline \multicolumn{7}{|c|}{ 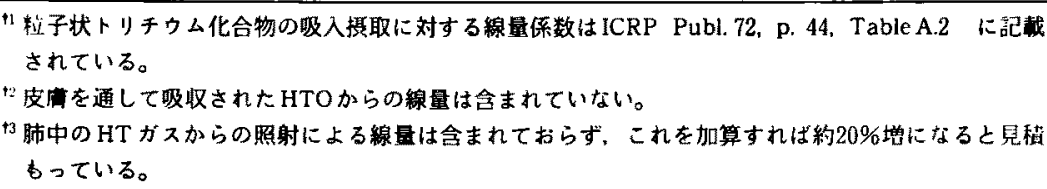 } \\
\hline
\end{tabular}

た1994年(9)には肺モデルの更新を行った。放射性核種に よっては, 線量係数が組織荷重係数や体内動態モデルの変 更によってかなり変化するため, ICRPはあらためて職業 人と一般公衆に対する線量係数を，それぞれPubl. $68^{(10)}$ およびPubl.72(11) として提示した。第 III-3 表に，公采に 対する線量係数を示す。被ばく形態としては，経口摄取で HTOとOBTが，そして吸入摄取では可溶性またはガス状 のトリチウムとして HTO, OBT, HT および $\mathrm{CH}_{3} \mathrm{~T}$ が考えら れている。なお，吸入摄取では粒子状のトリチウム化合物 あ考えられているが，この表からは除外した。職業人に対 してPubl.68で提示された線量係数の值は，この表中の成 人に対する各係数とまったく同じ值になっている。これ は,トリチウムに関して職業人と一般成人とが同じ体内動 態モデルに基づいて線量が算定されたためである。

第 III-4 表に，一般公䍃に対して設定された線量係数を 用いて算定したHTOに対する OBT，HTあるいは $\mathrm{CH}_{3} \mathrm{~T}$ の線量比を示す。この線量比の值は, OBTを経口摄取あ るいは吸入摄取した場合には，HTO摄取の場合より 3 ヶ 月齢で $1.7 \sim 1.9$ 倍高く，その他の年齢群で2.3〜2.5倍高

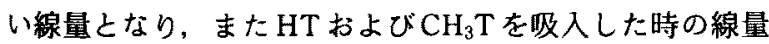
は，HTO吸入摂取の場合より 4 标および 2 桁低い線量と なることを示している。

第 III-4 表 線量係数から算定した化学形の違いによる線軍比

\begin{tabular}{|c|c|c|c|c|}
\hline \multirow{3}{*}{ 年 齿 } & \multicolumn{4}{|c|}{ 線 量比 } \\
\hline & \multirow{2}{*}{$\frac{\text { 経口摃取 }}{\text { OBT/HTO }}$} & \multicolumn{3}{|c|}{ 吸入提取 } \\
\hline & & OBT/HTO & $\mathrm{HT} / \mathrm{HTO}$ & $\mathrm{CH}_{3} \mathrm{~T} / \mathrm{HTO}$ \\
\hline 3 ヶ月齗 & 1.9 & 1.7 & $10^{-4}$ & $10^{-2}$ \\
\hline 1 歲 & 2.5 & 2.3 & $10^{-4}$ & $10^{-2}$ \\
\hline 5 歳 & 2.4 & 2.3 & $10^{-4}$ & $10^{2}$ \\
\hline 10 第 & 2.5 & 2.4 & $10^{-4}$ & $10^{-2}$ \\
\hline 15歳 & 2.3 & 2.3 & $10^{-4}$ & $10^{-2}$ \\
\hline 成人 & 2.3 & 2.3 & $10^{-4}$ & $10^{-2}$ \\
\hline
\end{tabular}

\section{一参考文献—}

(1) ICRP : ICRP Publ. 26, Pergamon Press, Oxford, (1977).

(2) ICRP : ICRP Publ. 6, Pergamon Press, Oxford, (1964).

(3) Report on amendments to ICRP Publ. 9, Health Phys., 17, 389 (1969).

(4) ICRP : ICRP Publ.60, Pergamon Press, Oxford, (1991).

(5) ICRP : ICRP Publ. 30. Pergamon Press, Oxford, (1978).

(6) ICRP : ICRP Publ. 61, Pergamon Press, Oxford, (1991).

(7) ICRP : ICRP Publ. 56, Pergamon Press, Oxford, (1989),

(8) 稻葉次郎：保健物理，25，247 (1990).

(9) ICRP : ICRP Publ. 66, Pergamon Press, Oxford, (1994).

(10) ICRP : ICRP Publ. 68. Pergamon Press, Oxford, (1994).

(11) ICRP : ICRP Publ. 72, Pergamon Press, Oxford, (1995).

\section{IV. 環境中トリチウム挙動}

\section{IV-1 グローバルおよび我が国における 環境中トリチウムの分布と挙動}

\author{
九州大学 百 島 則 幸*
}

半娍期12.3年のトリチウムが環境中に存在することが報 告されたのは1950年であった。宇宙線と大気構成原子の核 反応で生成しているトリチウムは，地球全体で見ると生成 と壊変が平衡した状態にある。その平衡存在量は地球全体 で1〜1.3EBq と推定されている(1)。大気上層で牛成した トリチゥムは雨として地上にもたらされ，陸水，地下水，海 水などに広く分布し，光合成で植物に，呼吸・飲料および 食物連銷を通して人に移行する。大気圈内核実験(特に 1954年以降の水爆実験）によるトリチウムの大量放出はそ れまでの睘境トリチウムの分布を一变させた。1963年の大 気圈内核奏験停止条約締結までに自然起源の200倍程度の トリチウムが環境へ放出されたと推定され，その結果とし て環境中のトリチウムレベルは大きく增加した。1963年以

* Noriyuki MOMOSHIMA, Kyushu Univ. 
降，環境トリチウムレベルは渐次減少傾向を示してきた が, 半筬期からすると, 現在は自然起源の30倍程度になっ ていると考えられる。これらのトリチウムの大部分はすで に地下水や深海水へ移行したと考えられるが, 水循環が遅 い(海洋との接触が少ない)大陸では, 核実験の寄与が強く 残っている。一方, 原子力関連施設から放出されるトリチ ウムは増加傾向にある。

\section{1. 降雨中のトリチウム濃度}

水爆実験開始前（1951～53年)の雨の HTO 濃度は 0.14 $7.9 \mathrm{~Bq} / /$ 範囲であったが, 1954 年春に行われた水爆実験 (Castleシリーズ)によりシカゴの雨の HTO濃度は一時的 に $53 \mathrm{~Bq} / l$ まで増加した。そして翌年にはほぼ以前のレべ ルに戻った。このように雨は核実験由来のトリチウムを最 6敏感に反映して変動した。1960年代初めに集中して行わ れた米ンの一連の核実験により雨の HTO濃度は著しく増 加した。オタワでは1963年に $700 \mathrm{~Bq} /$ /が観察され，我が国 であ東京, 川崎, 高知などで $12 \sim 180 \mathrm{~Bq} / l$ が測定され た ${ }^{(2)}$ 。1963年以降, 北半球では雨の HTO濃度は初夏の濃 度極大という季節変動を示しながら速やかに減少していっ た。オタワの雨の濃度極大は 1970 年には $40 \mathrm{~Bq} / l$ まで減少 し, 我が国のHTO濃度む1970年には $10 \mathrm{~Bq} / l$ 程度にまで減 少した。1970〜80年代になるとHTO濃度の減少は緩やか になり，そして1980年代後半以降はむはやはっきりした濃 度減少は我が国では観察されなくなった。1990年代に日本 各地で測定された值から判断すると，雨の HTOは核実験 以前の自然レベルにほぼ戻りつつあると推測される。

日本各地で測定された雨の HTO 濃度は, $0.7 \mathrm{~Bq} / l$ (福 岡；1993年), $1.2 \mathrm{~Bq} / l$ (福井；1992年), $0.8 \mathrm{~Bq} / l$ (千葉； 1988年)で，核実験開始前に測定された唯一の雨のデータ $0.77 \mathrm{~Bq} / l$ (神戸； 1953年)に近い值となっている。成層圈 におけるトリチゥムの平均滞留時間は $1 \sim 2$ 年と見積もら れていることから，核実験で成層圈に注入されたトリチウ ムはほとんど対流圈に降下したと考えられる。トリチウム の生成率は宇宙線強度で変化するため, 自然レべルのトリ チウム濃度は宇宙線強度に連動して変化していると考えら れる。したがって11年周期の太陽黒点活動の極小期に近い 1954年に採取された神戸の雨は,トリチゥム生成率の高い 時期のものと考えられる。極小期と極大期では $10 \%$ 程度卜 リチウム生成量が違うと推定されている。

韓国の雨 ${ }^{(3)}$ の HTO 濃度は $1.1 \mathrm{~Bq} / l(1991$ 年)で我が国の 值に近い。これは海に囲まれ，緯度がはぼ我が国と同じで あるためと考えられる。しかし，中国国境に近い北に位置 する白頭山(北緯 $41.5^{\circ}$ )では高い值 $(5 \mathrm{~Bq} / l)$ が観察されて いる。もともと雨の HTO 濃度には, 両極から赤道に向 かって指数関数的に娍少する緯度依存性 ${ }^{(4)}$ があることが， 核実験開始前に作られたふどう酒やグリーンランドおよび 南極の水の測定から明らかになっている。大気上層でのト リチウム生成率が歌地方で大きいことと, 成層圈から対流

圈へのトリチゥムの移行は極地ほど大きく，そして赤道付 近では蒸発による希釈が働くためと説明されている。この ような緯度依存性は核実験由来のトリチウムにあ観察され ている。核実験の影響が大きかった1960年代の雨のトリチ

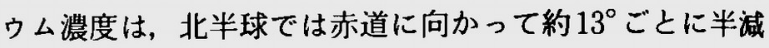
した。1986〜87年にかけて集められた我が国の雨の場合, 北海道は九州の約 2 倍の HTO 濃度を示している。しか し，白頭山で観察されたHTO濃度は上述の緯度依存性だ けで説明するには高すぎる。

中国大陸の HTO 濃度は我が国より高い。これは大陸に 降下した核実験由来のトリチウムが大陸内で蒸発と降雨を 繰り返すことで希釈を受けにくいためと解釈されている。 海に囲まれた我が国は海洋性気候に属し，海水による希釈 を大きく受けているためトリチウムレべルは低い。核実験 開始前からすでに，大陸は海洋地域と比べると1.8倍程度 高いHTO 濃度であったことがワインなどの分析からわ かっている(4)。もともとHTO濃度には地域差が存在して いたが，現在は核実験によってもたらされたトリチウムが まだ色濃く大陸に残っている状況といえる。我が国の天気 は大陸性気団と海洋性気団に支配されているが, 最近の雨 の HTO 濃度は気象状況と密接に関係している。大陸性気 団に覆われたときは大陸の影響を受け, 高いHTO濃度の 雨が降る傾向がある ${ }^{(5)}$ 。白頭山で観察された高いHTO濃 度は, 中国大陸の影響を受けやすい地理的要因が働いてい るためと考えられる。

\section{2. 大気中のトリチウム浱度}

大気中の $\mathrm{HT}$ と $\mathrm{CH}_{3} \mathrm{~T}$ のトリチゥム濃度の経年変化を第 IV-1 図に示す。濃度は大気 $1 \mathrm{~m}^{3}$ 当たりである。1950年代 初頭は $0.3 \mathrm{mBq} / \mathrm{m}^{3}$ 以下であった HT 濃度は, 核実験開始 と共に指数関数的に増加し，1960年代初めには $100 \mathrm{mBq} /$ $\mathrm{m}^{3}$ 以上にまで上昇した。1960年代後半から1970年代前半 にはHT濃度はほぼ横ばいを示していることがわかる。そ して，1970年代後半から1980年代にかけて緩やかな濃度減 少を示しているが，1990年代になると減少速度は非常に ゆっくりしたものよなっている。我が国で測定されている 最近の HT 濃度 ${ }^{(6)}$ は $28 \mathrm{mBq} / \mathrm{m}^{3}$ 程度で核実験開始前より 2

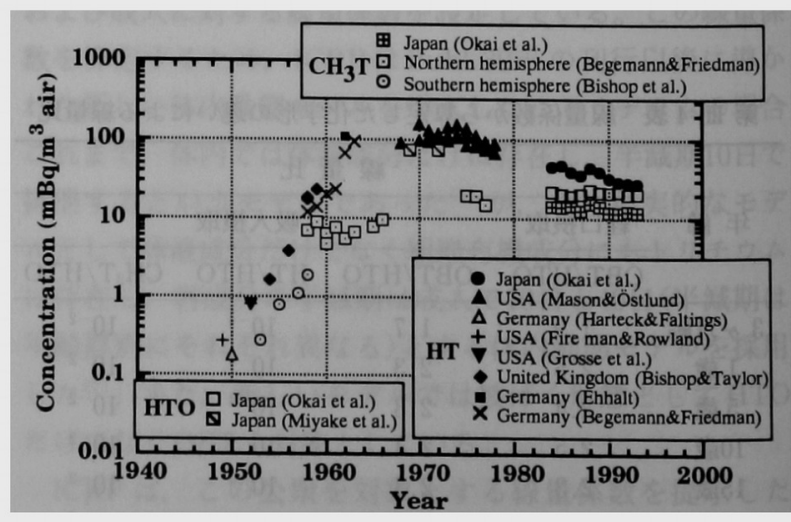

第 N-1 図大気中トリチゥム漬度の経年变化 
桁高い。放射壊変を考虑に入れたHT の滞留時間は4.8年 と見積もられている(7)ことから，1962年に観測されたHT の $340 \mathrm{mBq} / \mathrm{m}^{3}$ は現在では数 $\mathrm{mBq} / \mathrm{m}^{3}$ になっていなければ ならない。しかし, 現在の HT濃度は予測レべルより明ら かに高く，そして1988年には一時的に増加していることか ら, その発生源については今後の課題である。

一方, 核実験開始前の北半球の大気中 $\mathrm{CH}_{3} \mathrm{~T}$ 濃度の報告 はないが，南半球の測定結果を見ると，1952年の約 0.3 $\mathrm{mBq} / \mathrm{m}^{3}$ から增加している。北半球では1958年から1960 年代初めにかけて $\mathrm{CH}_{3} \mathrm{~T}$ 濃度に増加は見られず横ばいであ るが, HT濃度は大気圈内核実験により著しく增加してい る。この濃度増加の違いは大気中での HT から $\mathrm{CH}_{3} \mathrm{~T} へ$ の 変換が極めて遅いことを示唆している。1970年代に $\mathrm{CH}_{3} \mathrm{~T}$ 濃度は最大に達したと見られ，それ以後は極めて緩やかに 減少を続け, 最近の $\mathrm{CH}_{3} \mathrm{~T}$ 濃度は $12 \mathrm{mBq} / \mathrm{m}^{3}$ 程度となっ ている(6)。地球温暖化物質であるメタンの大気中での滞留 時間は 12 年とされている(8) ので, 放射壊変を考虑した $\mathrm{CH}_{3} \mathrm{~T}$ の帯留時間は 6 年程度と推定される。しかし, 1984 年以降, $\mathrm{CH}_{3} \mathrm{~T}$ 濃度に明確な減少は見られておらず, $\mathrm{HT}$ 同様その発生源については今後の課題である。

大気 $1 \mathrm{~m}^{3}$ 当たりの HTO 濃度は水蒸気量之そのトリチゥ 么濃度 $(\mathrm{Bq} / l)$ で決まるため, 季節変化を示し，場所で大 きく変わる。我が国では夏場の多湿期は冬季の乾燥期より HTO濃度は 4 倍ぐらい高い。第 IV-1 図に示すように, 最 近の福岡の HTO 濃度の年平均值 ${ }^{(6)}$ は $20 \mathrm{mBq} / \mathrm{m}^{3}$ 程度であ るが，1962年(10月)と1972年(8〜10月)に東京で測定され た HTO濃度は約 $70 \mathrm{mBq} / \mathrm{m}^{3}$ であった ${ }^{(9)}$ 。採取場所が違う ので直接の比較はできないが, 大気中HTO濃度は雨のト リチウム濃度ほど大きな経年变化を示していない。これは 雨は大気上層のトリチウムの影響(核実験により成層圈に 注入されたトリチウムの対流圈への降下)を大きく受けた のに対し, 地表面付近の水蒸気は土壌や植物による地下水 の蒸発散や表面海水との交換の影響を受けているためと考 えられる。

\section{3. 過去のトリチウムレベル推定}

植物は周辺の環境水を光合成を通して有機物に固定して いるので，樹木年輪中のトリチウム濃度から過去のトリチ ウムレベルを推定することができる。年輪の基本成分であ るセルロースを構成している炭素に直接結合している水素 は，化学的に安定で交換しないため光合成時のトリチゥム 濃度を記録している。水酸基やカルボキシル基の水素は水 分子と容易に交換反応を行うので, 蒸散活動で取り込まれ る環境水のトリチウムレベルが変化すれば変わりうる。

第 IV-2 図に千葉市と茨城県東海村に生育していたアカ マッの分析結果を示す(10)。千葉市は原子力施設の寄与が ない場所として選ばれたもので, トリチウム浱度は1963年 に $60 \mathrm{~Bq} / /$ の゚ーク値を示した後, 速やかに隇少している。 同じく施設の寄与が全くない福岡市で生育したスギ(11) は

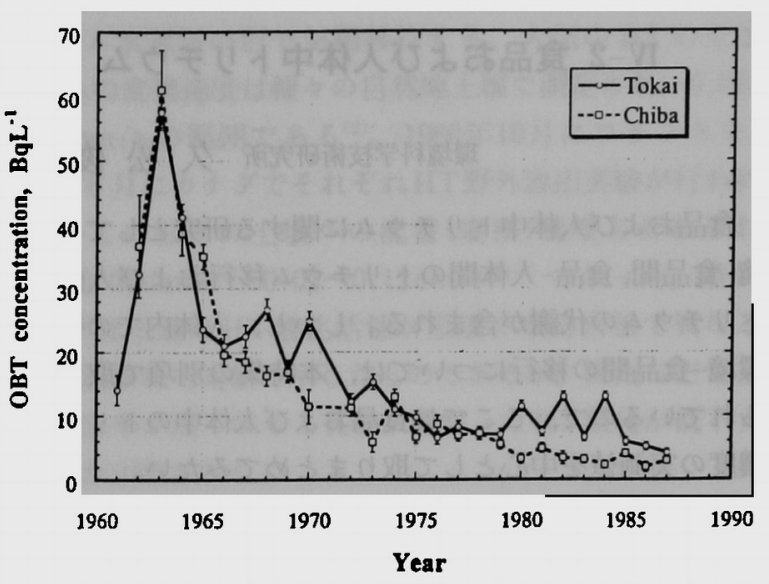

第 IV-2図 千葉市と東海村のアカマッ年輪中のトリチウム濃度

1963年に $76 \mathrm{~Bq} / /$ のピークを示していることから，1963年 の我が国のトリチウムレベルは $60 〜 80 \mathrm{~Bq} / l$ であったと考 えられる。注意しなければいけないことは, 年輪のトリチ ウム濃度は年輪形成時期(春から夏)の平均値を示している 点である。

1963年 4 月から 7 月にかけて東京で採取された雨の $\mathrm{HTO}$ 濃度の月平均は $120 \sim 150 \mathrm{~Bq} / l$ で(2), 年輪中に見い出 された值の約 2 倍である。山梨で作られた1963任産ワイ ン(2)のトリチゥム濃度は $90 \mathrm{~Bq} / l$ で, アカマッやスギの年 輪のデータに近い。トリチウム濃度の低い土壤水で雨のト リチウムは希釈されたことがわかる。一方，東海村のアカ マッの年輪には施設から放出されたトリチウムの寄与が見 られる。1968，1970，1973，1980～84年の年輪中のトリチ ウム濃度は千葉市のアカマッと比べると1.5 5.7倍高い値 である。施設から大気放出された水蒸気状トリチゥム (HTO)の葉からの直接の取込みと地表面への乾燥および 降水沈着後の経根吸収によるものと考えられる。しかし図 から明らかなように，施設からの寄与は1960年代始めに観 察された核㬰験によるものと比べてす小さ。

\section{一参考文献一}

(1) Okada, S., Momoshima, N. : Health Phys., 65, 595 (1993).

(2) Takahashi, T., et al : Radioisotopes, 18, 32 (1969).

(3) Ahn, J. S., Koh, Y. K. : Fusion Technol., 28, 793 (1995).

(4) Schell, W. R., et al. : IAEA-SM-181/34, 375 (1974).

(5) Matsuoka, N., et al. : Sci. Total Environ., 145, 197 (1994).

(6) Okai, T., et al. : Proc. 1996 SERNIA Symp. on Environmental Radioactive Nuclides Impact in Asia. Taipei, p.41 (1996)

(7) Mason, A. S., Ostlund, H. G. : "Behaviour of Tritium in the Environment", IAEA/STI/PUB 498, IAEA. Vienna, p. 3 16 (1979)

(8) 気象庁訳, 気象庁編：IPCC 第 2 次報告書「地球温喛化への実 態と見通し」, 125 (1995)

(9) 三宅康雄，他：環境問題特別号、日本地球化学会, p. 131 (1976)

(10) Fuma, S., Inoue, Y. : Appl. Radiat. Isot., 46, 991 (1995).

(11) Momoshima, N.: Radionuclides in "Plant Ecophysiology", (Ed. Prasad, M.N.V.), New York, John Wiley \& Sons, 457 (1996) 
IV-2 食品および人体中トリチゥム

\author{
環境科学技術研究所 久松 俊 一*
}

食品および人体中トリチウムに関する研究としては，環 境一食品間, 食品一人体間のトリチウム移行および人体中の トリチウムの代謝が含まれる。しかし，人体内での代謝や 環境-食品間の移行については，本特集の別項で取り上げ られているので, ここでは食品および人体中のトリチウム 濃度の実測值を中心として取りまとめてみたい。

実環境における食品および人体中のトリチウム実測例は 少なく，また，組織自由水トリチウム(TFWT)と OBT を 分別して双方を定量している報告はさらに希となる。 TFWT とOBTでは消化管吸収率や人体内での代謝が異な るため,トリチウム原子 $\left({ }^{3} \mathrm{H}\right)$ と $\mathrm{H} か ゙$ 平衡状態にない環境 では, 分別した測定值が望まれる。 ${ }^{3} \mathrm{H}$ と $\mathrm{H}$ が完全に平衡 状態となれば，食品および人体中のトリチウムの比放射能 は, 同位体効果によるわずかな差を除いてTFWT とOBT で同様となり，分別定量する意味はなくなる。しかし，例 えば，トリチウム取扱い施設周辺のような環境では，施設 からの排出量の増減に伴って非平衡状態となることが考え られ，TFWT，OBT双方について環境加人体への移行お よび人体内代謝を研究することが必要となる。

さて，1960年代を中心に米ンによって行われた核兵器実 験の結果, 多量のトリチウムか環境中に放出された。この フォールアウトトリチウムについては，1970年代に Bogen ら (1) (3) により米国の食品および人体中の濃度が測 定されている。さらに，イタリアのグループ(4)(5) が1980 年代初頭に測定值を発表している。これらの測定值に関す るまとめは既報(1) を参照されたいが，要するに，OBTの 比放射能が同じ試料中の TFWT に比較して，2 20倍程度 高いものであった。我々による最近の日本の測定例 (7) (12) ではもはやこのような大きな非平衡は認められないが，海 外で報告されている見かけ上の生物浱縮については議論が 残っている。トリチウム濃度を注意潹く制御した室内実験 では動植物による濃縮は認められない(13)。したがって, 見かけの濃縮の原因としては, 環境中トリチウムの季節変 動, 環境中でのトリチウムのメモリ一, 比放射能が TFWT に比較して 4 桁ほど高い空気中 $\mathrm{HT}^{(14)}$ の影響などが考え られている。この他，分析手法上の問題も挙げられる。

著者らは秋田市で1985 87年に採取した食品試料につい

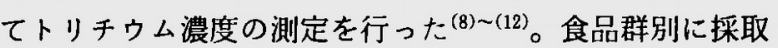
し，国民栄養調查成績による摄取量で重みを付けて合計し た値と，いわゆる日常食試料についての分析值を報告して いる。その結果, 前者と後者には大きな差は認められな かった。第 IV-3 図に，これらのOBT 濃度の平均値と標準 偏差を示す。図に見られるように，食品試料の OBT 平均

\footnotetext{
* Shunichi HISAMATSU, Inst. for Environ. Sci.
}

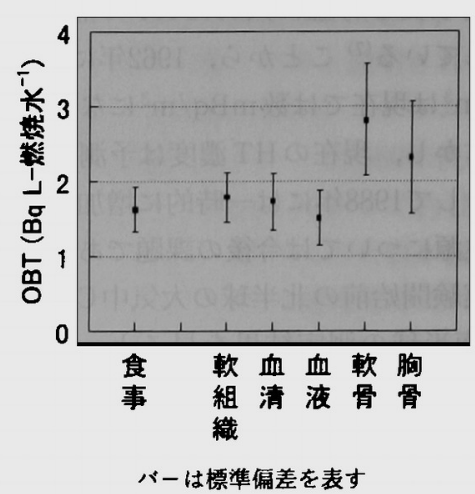

第 IV-3 図食事試料(1985 87年)と人体組織試料 （1986年）における平均OBT 濃度

濃度は $1.6 \pm 0.3 \mathrm{~Bq} / l$ であった。また，平均 OBT $/ \mathrm{TFWT}$ 比放射能比(SAR)は $1.0 \pm 0.2$ であった。四には秋田県内 で1986年に採取された人体組織試料についての分析 值 ${ }^{(7)(11)}$ もプロットしてある。人体組織のうち, 軟組織と 血清·血液試料は食事試料と同様な結果であり，この時点 では平衡に達していると見ることができる。血液について は, これに加えて，1990年に日本各地20地点から試料を採 取し、トリチウム濃度を测定している(15)。その結果, SAR の平均値は $0.8 \pm 0.3$ とやはり平衡と見なせた。ま た，第 N-4 図に示すように，OBT 濃度には緯度依存性が 見られている。

軟骨と胸骨のOBT 濃度は軟組織などとは異なり，高い OBT 濃度を示している(第 IV-3図)。これらの組織では水 素の代謝が遅く，過去の高濃度のトリチゥムが保持されて いると考えられる。そこで，コンパートメントの成長を考 虑したモデルを作成し，平均滞留時間を計算したところ， 軟骨については 57 年と推定できた(11)。このような極端に 代謝が遅い組織があるものの，全体としては人体内の TFWT とOBT は平衡となっており，前述のように食品に ついても平衡と見なせる。したがって，70年代でTFWT， OBT 間で非平衡が観測されている原因としての HT の影 響は可能性か薄くなったと考えられる。

日本人の OBT 摄取量に最も大きな寄与を与える単独の 食品は米であるが，井上ら ${ }^{(16)}$ は日本各地の白米を収集し てトリチウムを分析し，SARが1より小さいことを見出

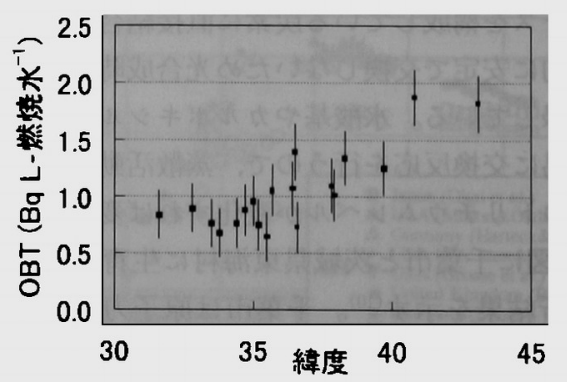

第 IV-4 図 日本各地より1990年に採取された血液中 OBT 濃度の緯度依存性 
している。著者らも刚り取り直後の粐米試料で,やはり SARが 1 を切っていることを確認している(17)。これにつ いて, 井上らは水田の環境では空気中湿分の HTO と潅溉 水中の HTOが平衡に近くなっているためではないかとし ている。裹返せば，他の作物では空気中の HTO と土壌中 のHTOが平衡からずれ，これが見かけの濃縮の一因とな る可能性を示唆している。

\section{一参考文献一}

(1) Bogen, D. C., et al. : “Tritium”, Messenger Graphics, Phoenix, TID-CONF-710809, 639 (1973).

(2) Bogen, D. C., Welford, G. A. : Health Phys., 30, 203 (1976).

(3) Bogen, D. C., et al. : "Behavior of Tritium in the Environment" STI/PUB/498, IAEA, Vienna, 567 (1979).

(4) Belloni, P., et al. : Radiation protection, European seminar on the risks from tritium exposure, Office for Official Publ. of the European Comm., Luxembourg, EUR 9065, 51 (1984).

(5) Clemente G. F., et al. : "Biological Implications of Radionuclides Released from Nuclear Industries", Vol. II, STI/PUB/ 522, IAEA, Vienna, 257 (1979).

(6) 久松俊一, 滝澤行雄 : Radioisotopes, 38, 381 (1989).

(7) Hisamatsu. S., et al. : Health Phys., 57, 559 (1989).

(8) Hisamatsu, S., et al. : Health Phys., 53, 287 (1987).

(9) Hisamatsu, S., et al. : Health Phys., 57, 565 (1989).

(10) Hisamatsu, S., et al. : J. Radioanal. Nucl. Chem. Articles, 156, 89 (1992)

(11) Hisamatsu. S., et al. : J. Radioanal. Nucl. Chem. Articles, 161, 455 (1992).

112 Hisamatsu, S., et al. : Health Phys., 63, 393 (1992).

(13) Diabate, S., Strack, S. : Health Phys., 65, 698 (1993).

(14) Okai, T., Takashima. Y. : Appl. Radiat. Isot., 42, 389 (1991).

(15) Hisamatsu, S., et al. : Health Phys., 68, 499 (1995).

(16) Inoue, Y., Iwakura, T. : J. Radiat. Res., 31, 311 (1990).

(1) Hisamatsu, S., et al. : J. Radiat. Res., 32, 389 (1991).

\section{IV-3 土壤, 水圈におけるトリチウムの挙動}

茨城大学 一 政 満 子*

原子力施設や核融合実験炉から，事故時あるいは平常時

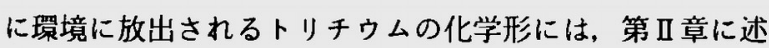
べられているように，HT, HTO, 有機型トリチウムがある

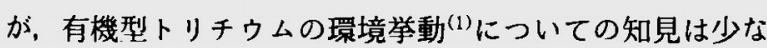
い。本節ではHT, HTOの土壌と水勝における挙動に関す る研究成果について簡単に述へよう。

\section{1. 土壤におけるHTの挙動一土壤での酸化}

HTOはHTに比べて 4 桁も体内に取り込まれ易いので， HT が環境でどのように酸化されるかが問題となる。HT は環境中では主として土壌で微生物により酸化され HTO となる。HTは水にほとんど溶けないので土壤中の甩粒の 孔隙の気相を移行し，水素酸化能を持つ土裹細菌により酸 化されて, HTOとして土裹の液相を移行する。一部はト

\footnotetext{
- Michiko ICHIMASA, Ibaraki Univ.
}

リチゥム水蒸気の形で気相移行する。大気中 HT の土壤 HTOへの変換速度は種々の自然地土壤で测定され, 0.001 $\sim 0.1 \mathrm{~cm} / \mathrm{s}$ の範用である(2)。1986年10月にフランスで, 1987年 6 月にカナダでそれぞれHT野外放出実験が行われ たが，このときの土裹への洸着(变換)速度もそれぞれ $0.01 \sim 0.05 \mathrm{~cm} / \mathrm{s}^{(3)}, 0.02 \sim 0.12 \mathrm{~cm} / \mathrm{s}^{(4)(5)}$ であった。第 IV - 5 図 ${ }^{(6)}$ は土壤の HT 酸化活性が土壤の水分含量で異なる ことを試験管内実験で示したすのであるが，降雨などで土 㖶の含水率が高くなると孔隙が塞がって HT 酸化が低下す ることが示晙された。

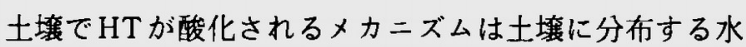
素酸化能を持つ特定の細菌によることを，HTの野外放出 実験と併せてその環境土壌試料での実験室試験管内実験に より著者らは具体的に明らかにした(7)。12日間に及ぶHT 野外連続放出実験が1994年夏に, カナダのチョークリバー 研究所の実験圃場で行われた ${ }^{(8)}$ 。実験围場は耕作地と自然 地からなり，表層土境の HTO濃度は放出期間を通して耕 作地より自然地の方が変動はあるむのの数倍高く ${ }^{(9)(10)}$, 土壤深度に従って HTO濃度は減少した ${ }^{(9)(11)}$ 。また，地表 から $5 \mathrm{~cm}$ 刻みで深さ $20 \mathrm{~cm}$ まで分画採集した自然地と耕作 地の HT 酸化活性（試験管内実験)は, 自然地表層土壌 $(0 \sim$ $5 \mathrm{~cm})$ では耕作地 $(0 \sim 5 \mathrm{~cm})$ の約 4 倍で，自然地では深さ ととすに減少したが，耕作地では鋤起こしのため深さ 20 $\mathrm{cm}$ までほぼ均一であった $\left(\right.$ 第 N-6 図) ${ }^{(7)}$ 。これらの土袞か ら土壤細菌を分離し，その内で HT(水素)酸化能を持つ細 菌を検索したところ，その出現率は自然地の表層土壤 $(0$

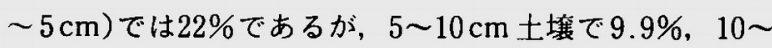
$15 \mathrm{~cm}$ で $8.1 \%, 15 \sim 20 \mathrm{~cm}$ では $4.8 \%$ と減少し(第 IV-1 表 $)^{(7)}$ ，また耕作地土境 $(0 \sim 5 \mathrm{~cm})$ では $7.5 \%$ で，第 $\mathrm{IV}-6$ 図の HT 酸化活性分布とほぼ同じパターンであった。HT を酸化する分離菌株は主として Streptomyces 属の放線菌 であった。すなわち、これらの細菌が土壤のHT酸化能の 実体であることを示している。

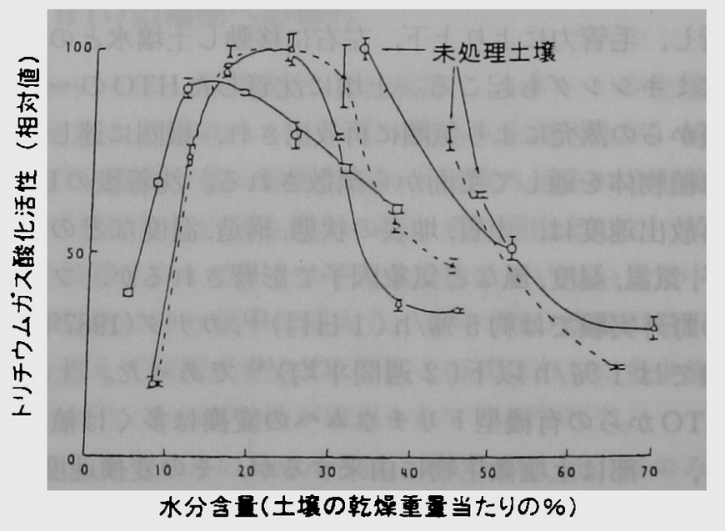

$\Delta$ : 水出土垻 $(0 \sim 5 \mathrm{~cm}) ； \triangle$ : 姆土墥 $(0 \sim 5 \mathrm{~cm})$ ；

○:林間草地上塔 $(0 \sim 5 \mathrm{~cm})$

土垬試料は乾嬠または加湿処理により水分含量を調節した。

第 IV-5 図 十:境のトリチウムガス酸化活性に及ぼす 水分含量の影響(6) 
第 IV-1 表 自然地土埕画分における 3 種の培地での生菌数とHT 酸化細菌の分離(7)

\begin{tabular}{|c|c|c|c|c|c|c|c|}
\hline \multirow{2}{*}{$\begin{array}{c}\text { 土袞画分 } \\
\text { (深度) }\end{array}$} & \multicolumn{3}{|c|}{ 生菌数 $\left(\times 10^{6}\right.$ 菌数 $/ g$ 土埕 $)$} & \multicolumn{3}{|c|}{ HT 酸化細菌数/分離菌株数 } & \multirow{2}{*}{$\begin{array}{c}\text { HT 酸化菌 } \\
\text { 総出現率 } \\
(\%)\end{array}$} \\
\hline & $\mathrm{N}$ 培地 & S 培地 & $\mathrm{A}$ 培地 & $\mathrm{N}$ 培地 & $\mathrm{S}$ 培地 & $A$ 培地 & \\
\hline $0 \sim 5 \mathrm{~cm}$ & 16.6 & 16.7 & 19.3 & $29 / 200$ & $39 / 200$ & $64 / 200$ & 22 \\
\hline $5 \sim 10 \mathrm{~cm}$ & 2.2 & 3 & 3.3 & $0 / 62$ & $1 / 86$ & $21 / 74$ & 9.9 \\
\hline $10 \sim 15 \mathrm{~cm}$ & 1.6 & 2.2 & 3.2 & $1 / 35$ & $0 / 69$ & $13 / 69$ & 8.1 \\
\hline $15 \sim 20 \mathrm{~cm}$ & 1.3 & 2.1 & 1.9 & $0 / 54$ & $0 / 71$ & $9 / 64$ & 4.8 \\
\hline
\end{tabular}

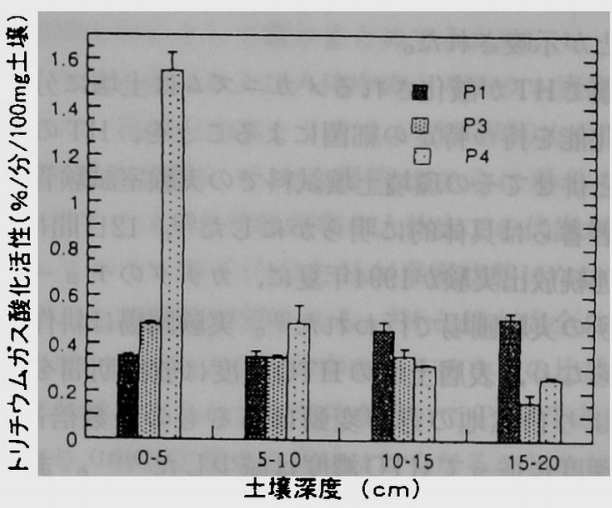

第 IV-6 図 実験㺷場の耕作地（プロット1，3）と自然 地(プロット4)からの土壇試料のトリチウ ムガス酸化活性の深度分布 ${ }^{(7)}$

\section{2. 土壤におけるHTOの挙動}

大気水蒸気中の HTO は土壤中に水蒸気拡散・交換で沈 着する。トリチゥム水蒸気の裸地土壌への沈着速度の測定 值は $0.09 \sim 0.91 \mathrm{~cm} / \mathrm{s}^{(12)}$ であるが, 植物や落葉等に覆われ ていると, 土㙵への拡散は妨げられ沈着速度はかなり低く なる。水蒸気はその気圧の高い方から低い方へ拡散する。 土壤中の空気の相対湿度は土壤表層数 $\mathrm{cm}$ を除けばほぼ 100\%であることが多いが, HTO濃度の高い方から低い方 へ水蒸気の正味の輸送がない場合です拡散する。土壤の水 に入ったHTOは土壤水とともに下降方向へ重力により移 行し, 毛管力により上下, 左右に移動し土壤水之の不均一 なミキシングも起こる。土壤に沈着したHTOの一部は地 表からの蒸発により気圈に再放出され, 根圈に達した一部 は植物体を通して葉面から蒸散される。沈着後のHTOの 再放出速度は, 土質, 地表の状態, 構造, 温度などの土境因 子, 気温, 湿度, 風など気象因子で影響されるが，フランス の野外実験では約 $5 \% / \mathrm{h}\left(1\right.$ 日目) ${ }^{(3)}$,カナダ(1987年)の実 験では $1 \% / \mathrm{h}$ 以下 $(2 \text { 週間平均 })^{(4)}$ であった。土壤中の HTOからの有機型トリチゥムへの変換は多くは植物によ り, 一部は土境微生物に由来するが, その変換速度は HT のHTOへの変換に比べると非常に小さい(2) と考えられて いる。

\section{3. 水圈におけるトリチゥムの挙動}

川, 池, 湖等水圈におけるグローバルなトリチウムの挙動
は水循環に関する研究から明らかにされる。川の水は大 部分, 川の流域の降雨に由来するが, 上流地域の地中に浸 透した雨水が地下水に入り, 湧水として流出する地下水流 出と地表流として直接流出するすのからなり, 地下水を経 由する経路は川に至るまでかなり時間がかかる。川の水の トリチウム濃度は流域の降雨より高くなることがある。降 水のトリチウム濃度は1952年以降の核実験により大きく増 大し，ピーク濃度は1963年であったが，それ以降は季節変 化を伴いながら徐々に低下し，現在はほとんよ゙バックグラ ウンドレベルとなっている。地下水中のトリチウム濃度の 空間的なパターンを降雨水のトリチゥム濃度の時系列デー タと比較することによって地下水の流動の方向と年齢を推 定できる。千葉県市原の養老川下流域での地下水のトリチ ウム濃度の計測 ${ }^{(13)}$ では, 台地で涵養された地下水が低地 に向かって流動し，地下水の年齢は台地上部で 10 年から 10 数年であるが, 台地縁辺部では 30 年を超えていた。地下水 が带水層を通って動く速度は変動幅が大きく，一般に 1.5 $\mathrm{m} / \mathrm{yr}$ から $1.5 \mathrm{~m} / \mathrm{d}$ であるが，高度に浸透性の帯水層では 速度が数 $100 \mathrm{~m} / \mathrm{d} に$ にることがある(2)。事故などで HTOが直接, 川に流入した場合は, 川の水による希釈, 分 散, 乱流拡散などの状況によりトリチウム濃度は決まる。

池の水量は多くの場合, 他の水源からの流入や流出より す降雨での供給と蒸発での消失が大きく, 池面の風の作用 でよく混合される。池のトリチウム濃度は表面からの HTOの水蒸気移行で大気に拡散し, 池のHTOの滞留時間 は水蒸気交換に依存する(14)。湖では,川のようであるか, 流れが比較的少なく池に似ているか, 季節的な湖水の層の 循環があるとか, 湖によりその特性が大きく異なるため, HTOの滞留時間は数日から数年まで(2)多様である。

陸上のトリチゥム発生源から海へのトリチウムの移行 は, 河川水の流出, 陸上大気の海への移行, 地下水加らの直 接流出による。海におけるトリチゥムの移行に関する知見 の多くは，1960年代はじめに行われた成層圈での核実験で 放出されたトリチウムの移行の研究に由来するが, 海に 入ったトリチゥムと対流圈の大気中トリチゥム濃度の湘定 から, 海へのトリチウム沈着は, 大陸への沈着よりも大き いこと，その大部分は乾性沈着であること(15) が示された。

最近, 一政ら ${ }^{(16)}$ は我が国の海水や湖水の HT 酸化能を調 べ, 土壤に比べると非常に弱いながら酸化が行われること を明らかにし，その海水や湖水から $\mathrm{HT}$ 酸化能を持つ細菌 を分離している。水圈の酸化能は土境に比べると弱いが, 
土埕表面はしばしば植物で覆れていてその分酸化能は低下 する。これに対して水面を遮るものは通常ほとんどないの で，浅い池や沼のような流出入の少なく，その環境で水面 の占める割合が大きい場合は，水面での酸化を評価に入れ ることを検討する余地があろう。

水生生物は体内の水と周りの水との交換速度は高いの で，水生生物の組織のトリチウム濃度は数時間以上の放出 では周りの環境水の濃度と同程度になる。水生生物の藻類 のOBTは, 光合成によりHTOから取り込まれたものと陸 生や水生起源のトリチゥム化有機堆積物(デトリタス)から 取り込まれたものである。したがってトリチウム化デトリ タスが周りの水より高いトリチウム濃度であれば，藻類の 有機物むまた周りのトリチウム濃度より高くなるであろ う。デトリタス中のOBTにはより低いターンオーバー速 度を持つものがあるので, 核実験の影響とみられる周りの 水上り高いトリチウム濃度のデトリタスが報告されてい る(17)。水生生物では食物連鎖を通してのトリチウムの生 物学的濃縮は, 研究室での実験でも野外環境での試料です 見られていない。

\section{一參考文献一}

(1) Diabate, S., Strack, S. : Health Phys., 65, 698 (1993)

(2) Murphy, C. E. Jr. : Health Phys., 65, 683 (1993).

(3) Paillard, Ph.: Fusion Technol. 14, 1226 (1988).

(4) Ogram, G. T., et al. : Fusion Technol., 14, 1170 (1988).

(5) Noguchi, H., et al. : Fusion Technol., 14, 1187 (1988).

(6) Ichimasa, M., et al. : J. Radiat. Res., 29, 144 (1988).

(7) Ichimasa, Y., et al. : Fusion Technol, 28, 877 (1995).

(8) Davis, P. A., et al. : Fusion Technol., 28, 840 (1995).

(9) Davis. P. A., et al. : Fusion Technol., 28, 833 (1995).

(10) Noguchi, H., et al. : Fusion Technol., 28, 924 (1995).

(11) Amano, H., et al. : Fusion Technol., 28, 803 (1995).

(12) Garland, J. A., et al. : "Behavior of Tritium in the Environment ${ }^{n}$, IAEA-SM-232/74, Vienna, IAEA, 349 (1979).

(13) 近藤昭颜: 地理学評論, 58,168 (1985)

(14) Horton, J. H., et al. : Envir. Sci. Tech., 5, 338 (1971).

(15) Weiss, W., et al. : "Behavior of Tritium in the Environment", IAEA-SM-232/74, Vienna, IAEA, 315 (1979).

(16) 一政倹輔, 他 : 放射線影響学会第39回大会講演要旨集， p. 383 (1996).

(17) Bogen, D. C., Welford, G. A. : Health Phys., 30, 203 (1976).

\section{IV-4 植物中におけるトリチウムの挙動}

日本原子力研究所 天野 光*, 新 麻里子*

環境に放出されるトリチウムが植物に取り込まれるプロ セスの解析は，植物を動物が搷取し，またトリチウムを含 む動植物を人間が㩒取することから重要である。

原子力施設から放出されるトリチウムの要な化学形は HTOやHTであるが，環境中には $\mathrm{CH}_{3} \mathrm{~T}$ やその他㮔々の

- Hikaru AMANO, Mariko ATARASHI, Japan At. Energy Res. Inst.
OBTとしてのトリチウムも存在する。

被ばく線量としては，本特集の第 III-3 節で報告してい る通り，ICRPは例えば同じ量のトリチゥムが人間に吸入 摄取された場合, HTOはHTの $10^{4}$ 倍, $\mathrm{CH}_{3} \mathrm{~T}$ の $10^{2}$ 倍であ るが，有機結合型の形態はHTOのさらに2.3倍であり， また，植物組織等に有機結合したトリチウムの経口摄取線 量はHTO 経口掑取のさらに2.3倍と詊洒している。HTO の事故的放出では，食物搷取による線量は吸入および皮首 から取り込まれるトリチウムによる線量の数倍〜数10倍高 いという評価もなされている(1)。こうしたことから，トリ チゥムの植物への移行, 特に野菜や果物の可食部への移行 プロセス, さらに光合成により有機化し有機生成物として 可食部へ移行するプロセスの解析が重要である。また，植 物葉中の HTO は比較的簡単に水により除去される(2) のに 対して，植物に有機結合したトリチウムは除去困難であ る。こうしたことからす根や実への移行の解析や有機化プ 口セスの解析は重要である。根や実へ移行したトリチウム はHTO形であっても，簡単には除去されないからであ る。また，本特集の第 $\mathrm{N}-1$ 節であふれているが， OBTの 安定性に着目して, 樹木の年輪中に固定されたOBTを用 いて，過去のトリチウム污染の経年変化をモニタリングす ること舟行われている(3)(4)。

植物の葉へのトリチウムの取込みに関しては，化学形が HTOについては理論的解析あ含めてよく調べられてい る(2)(5) (9) が, $\mathrm{HT}^{(10) \sim(13)} お よ ひ ゙ \mathrm{CH}_{3} \mathrm{~T}^{(14)}$ についても実験 が行われている。核融合関連施設から放出が予想される HTトリチゥムの植物への取込みに関しては，HTトリチ ウムそのむのの植物への移行は無視できるほどであるが, 放出されるHTが環境中，特に表面土湲中に棲息している 微生物によりHTOに化学形が転換した後, 植物に取り込 まれる動態は被暴線量評価上も重要で詳しく調べられてい $3^{(15)(16)}$ 。また, トリチウムに関しては植物に濃縮される ことはない(17)。

\section{HTOの植物への移行}

Raney らは，植物をポット栽培し，ポットの土墥に HTOを加え，植物のトリチウム取込みを調べたが，植物 葉中HTO濃度が葉の蒸散作用により取り込まれる土壤水

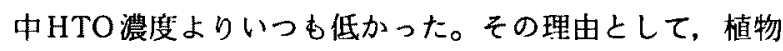
の葉の気孔を介して、トリチウムを含んでいない大気中水 蒸気が拡散により葉中に侵入し, 葉中HTO濃度が希釈さ れると考えて解析式を立てた ${ }^{(5)}$ 。この式はのちに多少修正 されたが(9)，その有効性か確認されている(2)(9)(16)。

一カ、フランスのBelot らは, HTOが大気中にのみ存 在する場合, HTOが葉の父孔を介して, 大気から植物に 㹡散により取り巡まれるプロセスを動的に解析した ${ }^{(6)}$ 。こ の式の有效性はすでに確認されているが(2)(7)，ある種の樹 木の葉については，昖散による交換に関与しない隔離水が 葉の中に存在していることが認められている(2)。しかしな 
がら，人父仂ら葉に取り込まれたHTOが実や根に移行す る過程や，土垬から植物の各部位に移行する過程はそれ机 ど詳しくは調べられてはいない。

\section{2. $\mathrm{HT} よ ひ ゙ \mathrm{CH}_{3} \mathrm{~T}$ の植物への移行}

化学形が HT および $\mathrm{CH}_{3} \mathrm{~T}$ については, 化学形が HTO のあのに比べ植物に余り取り込まれないことが実験により

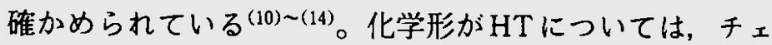
ンバー実験で, 例えば葉への沈着速度が $2 \times 10^{-6} \mathrm{~cm} / \mathrm{s}$ と 評価されている(13)。 $\mathrm{CH}_{3} \mathrm{~T}$ についても植物に取り込まれる が，その機構は不明で， $\mathrm{CH}_{3} \mathrm{~T}$ が炭素を含むのと，わずか ながらも水に溶けることから光合成のプロセスとして植物 に取り込まれ有機化する可能性が指摘されている( ${ }^{(14)} 。$ ま た，量的には少ないが、ホルムアルデヒドの形のトリチウ ムがある種の原子力施設から放出される場合もある(18) が, この形のトリチウムは植物によく取り込まれる可能性があ り, 植物生理学的観点から興味がある。

\section{3. 植物中 OBT の生成}

光合成は光の存在下で $\mathrm{CO}_{2}$ と水により植物が有機物を合 成するプロセスであるが，この時，水にトリチウムが含ま れれば, OBTが植物中に形成される。この光合成による OBT の形成は, 植物の種類や成長段階により異なり, 葉 に生成された OBT が植物体内を転流し，植物体中のどこ にどれだけ蓄積されるか等, 詳細な解析が必要である(19)。 このことは, 例えば植物の成長段階に応じて事故等により 放出されるトリチウムが植物に取り込まれ有機化する様子 が異なるからである(19)。我が国は米を主食としており， 米の成長段階のどの時期にトリチゥムが稻穂に取り込まれ るか等, 明らかにしておく必要がある。

\section{HTガス連続放出時における植物への}

\section{トリチウムの移行}

1994年 7〜8 月にカナタのチョークリバー研究所の敷地 内野外実験場で，HTガスの連続放出実験が行われた。放 出期間は 12 日間で，こまつな, こニトマト，ラディッシュ (はつか大根)への取込みが調べられた(16)。HTガスが地表 に棲息しているバクテリアにより HTOに化学形が転換 し，HTOに転換したトリチウムが大気および土壤から植 物に取り込まれた。第 IV-7 図に, HT ガス放出開始から 放出終了までにわたっての，植物可食部中および大気，土 壤水中の HTO 濃度を示す ${ }^{(16)}$ 。 HT ガス放出開始後、こま つなの葉およびラディッシュの根中HTO濃度は, 大気㧍 よび地表土壤水中 HTO 濃度とともに急激に上昇したが, トマトの実については，その上昇は緩やかであった。図中 の縦矢印と数字は実験期間中に起こった降雨とその降雨量 であり，降雨があれば，トマトの実を除いて一時的に HTO 濃度が減少するがすぐ回復することがわかる。第 IV -8 図に，HT ガス放出開始から放出終了までにわたって

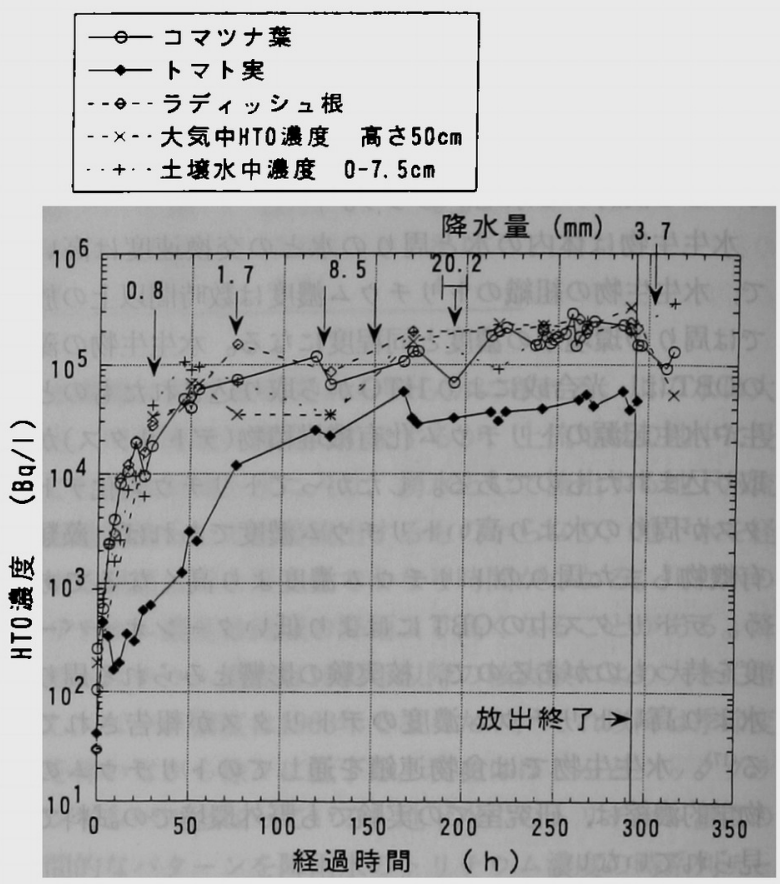

第 IV-7 図 植物可食部中 TFWT 濃度および大気, 土壤水中 HTO 濃度 ${ }^{(16)}$

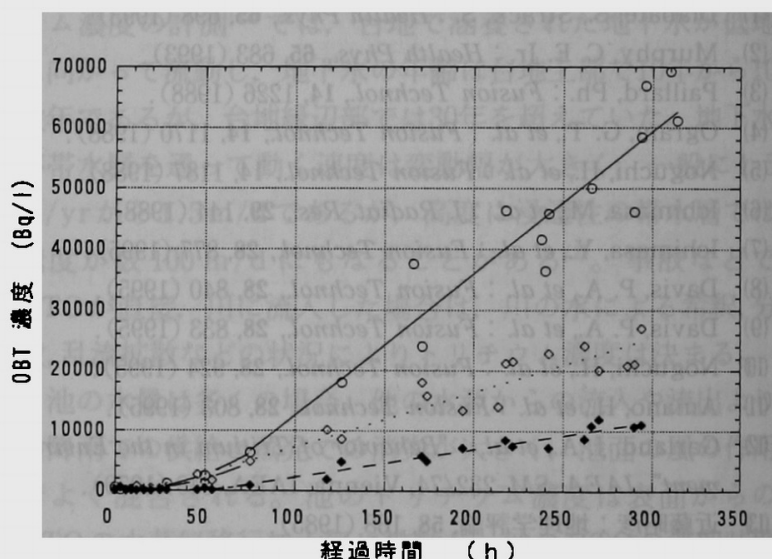

経過時间 ( h )

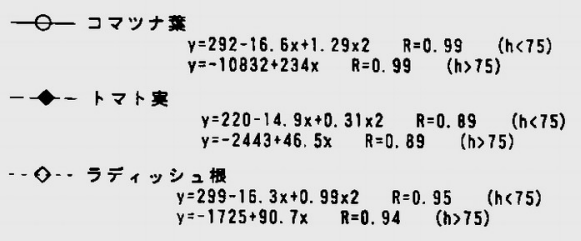

第 IV-8 図 植物中OBT 濃度変化 ${ }^{(16)}$

の, 植物可食部中 OBT 濃度の経時変化を示す $(16)$ 。 HT ガ 不放出開始後, 3 日目頃から $\mathrm{OBT}$ 濃度は直線的に上昇し たが，12日の放出期間では平衡に達しなかった。

\section{5.おわりに}

本稿で, 植物のトリチゥム取込みについて概説した。 HTOの植物の葉への取込みに関しては, その機構を含め てかなり解明されている。葉以外の組織，特に食物として 
利用される大根や人参, トマトの果肉, 豆等人の移行の評価 は重要である。HTおよび $\mathrm{CH}_{3} \mathrm{~T} ト$ リゥムの植物の葉へ の移行に関しては，その機構等はほとんどわかっていない が，移行量はわずかである。光合成による有機結合化，植 物組織への転流に関しては，特に植物の可食部について定 量的な評価が将来重要であろう。また本稿で言及した以外 の化学形のトリチウムの放出が考えられる場合，その評価 あ必要である。

\section{一参考文輔一}

(1) Gulden, W., Raskob, W. : Fusion Technol., 21, 536 (1992).

(2) Amano, H., Garten, Jr. C. T. : Environ. Int., 17, 23 (1991).

(3) Kigoshi, K., Tomikura, Y. : Bull. Chem. Soc. Jpn., 34, 1738 (1961).

(4) Amano, H., et al. : ORNL/TM-10438 (1987)

(5) Raney, F., Vaadia, Y. : Plant Phys., 40, 383 (1965).

16) Belot, Y., et al. : Health Phys., 37, 575 (1979).

(7) Garland, J. A., Cox, L. C. : Water Air Soil Pollut., 17, 207 (1982)

(8) Spencer, F. S. : $O H-84-69-K$, (1984)

(9) Amano, H., Kasai, A. : J. Environ. Radioact., 8, 239 (1988).

(10) Garland, J. A., Cox, L. C. : Water, Air Soil Pollut., 13, 317 (1980).

(11) Sweet, C. W., Murphy. C. E. Jr. : Environ. Sci. Technol.. 18, 358 (1984).

112 Spencer, F. S., Dunstall, T. G. : Radiat. Prot. Dosim., 16, 89 (1986)

113 Murphy, C. E. Jr. : Proc. 3rd Japan-US Workshop on Tritium Radiobiology and Health Physics, IPPJ-REV-3, p.64 (1989).

(14) Amano, H. : Fusion Technol, 28, 797 (1995).

115) Spencer, F. S., et al. : Fusion Technol., 14, 1176 (1988).

(16) Amano, H., et al. : Fusion Technol., 28, 803 (1995).

(17) Mcfarlane, J. C. : Environ. Exp. Botany, 16, 9 (1976).

(18) Belot, Y., et al. : Fusion Technol., 21. 556 (1992).

(19) Diabate. S., Strack, S. : Health Phys., 65, 698 (1993).

\section{IV-5 線量評価モデルとパラメータ}

日本原子力研究所 野口 宏*, 横山須美*

\section{1. 評価モデルの種類}

原子力施設に起因する公衆被ばく線量を評価するための モデルは，その目的に応じて施設の安全評価用, 挙動解析 のための研究用, 防災対策用などに分けられる。我が国で は,トリチゥムに関して今後，核融合叔を対象とした安全 評価モデルの開発が大きな課題であると考えられる。以 下，大気中に放出されたトリチウムの安全評価モデルとそ の基となる挙動解析モデルについて見状と課題を述べる。

\section{2. 事故時評価モデルの現状と課題}

トリチゥムが事故的に大気中に放出された場合の公衆被

* Hiroshi NOGUCHI, Sumi YOKOYAMA, Japan At. Energy Res. Inst.
ばく線量を評価することを目的とし，かつトリチウム特有 の環境中举動を考慮した計算コードは，これまでにいくつ 加開発されている。代表的なコードとしては，ドィッの $\mathrm{UFOTRI}^{(1)(2)}$, カナダの ETMOD ${ }^{(3)}$, 原研の TRIDOSE ${ }^{(4)(5)}$ などがある。これらのコードは以下の特徴を有している。

核融合灯からは，主としてHTおよびHTOの化学形の トリチウムが大気中に放出されると考えられる。このた め，いずれのコードも HT と HTO放出に対応したものと なっている。また，大気中HTおよびHTOの土壤への沈 着, 土壤中での HTO移行, 土樭中HTOの大気および植 物への移行，大気中 HTOの植物への移行等がモデル化さ れている。

第 IV-9 図にTRIDOSEで考慮されているトリチウムの 環境中移行経路を示す ${ }^{(5)}$ 。このコードは挙動解析用である ので, 空気中トリチウムの呼吸摄取経路上食物中トリチウ ムの経口摄取経路が考虑されているが，我か国における事 故時の安全評価上は呼吸経路が重要と考えられる。

上記のコードはいずれる大気㹡散式にはガウスプルーム モデルを使用している。また，大気へ放出された HTまた はHTO の地表面への沈着と HTOの大気への再放出を考 慮している。この現象をモデル化するために，いずれの コードも地表面をメッシュ状に区切り，各区画にHTまた はHTO が沈着し，それぞれが HTO の放出源になるとし ている。また, TRIDOSE は, 風下方向へ 2 次フルームが 移動する間に再び土壤一大気間で沈着と再放出を繰り返す 現象を忠実にシミュレーションできるようになっている。

食物掑取に上る事故時の被ばく線量評価は, 我が国の規 制では要件とされていないが，トイッでは必要とされてい る。このため, UFOTRI は事故時の食物連銷に上る公䍃 被ばく線量を詳細に評価できる。

UFOTRIを用いて，種々の気象および放出条件につい て計算された線量結果が報告されている(6)。例えば，放出 高さが $150 \mathrm{~m}$, 放出時間が $1 \mathrm{~h}$, 大気安定度が $\mathrm{F}$, 風速が 0.5 $\mathrm{m} / \mathrm{s}$, トリチゥム放出量が $1 \mathrm{GBq}$ の条件では, 風下 $1 \mathrm{~km}$ 地

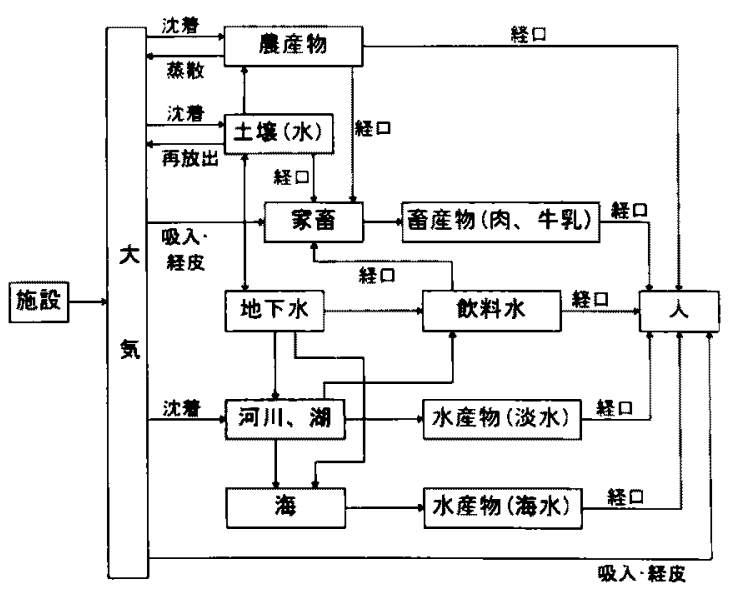

第IV-9図 TRIDOSEで考虑されている被ばく経路(5) 
点における線量はHT放出に対して $6.60 \times 10^{-13} \mathrm{~Sv}$ ，また HTO放出に対して $1.03 \times 10^{-11} \mathrm{~Sv}$ と評価されている。し たがって，この場合，HTO放出時の線量はHT放出時の 約16倍である。被ばく経路としては，経口摄取が最も大き く，HT放山の場合で98\%，HTO放出の場合で83\%であっ た。経口搷取以外では，HT放出の場合は土壤中で酸化さ れた後，大気中へ再放出したHTOによる吸入線量が大き かった。また，HTOの場合は施設から放出されたHTOを 㨁接吸人することによる線量が大きかった。

我か国では，原子力施設に関する公衆被ばく線量評価は 原子力安全委員会の「気象指針」(7) 等に基づいており，核 融合炉の場合においても指針との整合性が重要となろう。 しかし，前述のコードはいずれもこのような要件を満たし てはいない。このため,今㣪トリチウム放出に対応した安 全評価用コードを開発する必要があると考えられる。原研 では現在この開発に着手したところである。この際の課題 として、トリチゥム特有の挙動を考虑した上で,「気象指 針」に従った年間の寒気象データを使用した事故時の線量 計算法等との整合性に配慮する必要があろう。

\section{3. 平常時評価モデルの現状と課題}

核融合炉の平常運転時では, 大気中へHTOとHTが放 出されることが想定できるが，線量評価上はまずHTO放 出に対応する必要があろう。平常時のHTOによる被ばく 経路としては，吸入攝取と食物攝取経路を考虑しなければ ならない。再処理施設の安全評価においては，HTO放出 に対する食物摄取経路に関して比放射能法, すなわちトり チゥムで污染した農畜産物中 HTOの比放射能は空気中 HTOの比放射能と同じであると仮定して計算する方法を 用いている(8)。この方法は，必ずしも現実的な線量を与え るものではないが, 安全側の值を算出することができる。 したがって，核融合灯の安全評価においても，比放射能法 は有効な方法であると考えられる。しかし，最近の知見に よると，植物中ではOBT が生成されることが明らかに なってきたので、この経路についても評価できるようにし ておく必要があろう。UFOTRIではOBTの生成も考慮し ており，これによると典型的なドイッの農産物(小麦、ジャ ガイモ等)が収檴前の30日間HTOに懪された場合, 農産 物の経口攝取による被ばく線量の約 $80 \%$ はOBTに起因す るとの結果が報告されている(9)。

平常運転時のHT放出に対応した線量評価コードとして は、ドイッの NORMTRI ${ }^{(10) や カ ナ タ ゙ の ~ C E D M-H T ~ か ゙ あ ~}$ る(11)。これらのコードはHTの1次プルームによる空刘

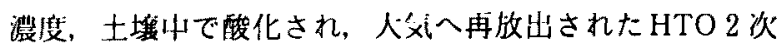
プルームによる空気中濃度，農音産物中HTOおよびOBT 濃度などの平衡濃度から被ばく線量が詊価できる。

ITERの場合, 平常運転時に放出されるトリチウムは熱 交換器や冷却系からの漏洩によるもの, すなわちHTOと 考えられる成分の割合が多いと推定されており"1ッ, 線量
評価上はHTOに支配されると考えられる。しかし，放出 されるトリチウムがすべてHTOと仮定した場合とHT/ HTO混合放出の場合を比較し，前者の仮定の安全裕度の 推定や将来の核融合炬の精度よい線量評価のために，平常 時の HT 用線量評価コードを開発することも重要な課題で ある。

\section{4. モデルの検証}

環境中における放射性核種の挙動および線量評価用モデ ルの検証は，計算結果の信頼性を確認し精度を向上させる ために重要である。このような検証のための国際的な協力 研究として, 生態圈中移行モデル検証計画(BIOMOVS 計 画)が1986から1996年まで実施された。

トリチウムについても特殊な放射性核種の一つとして BIOMOVS計画のフェーズ II (1991〜96年)で取り上げら れた。トリチウムモデルの検証には，原研を始め，ドイ ッ,カナダ、スウェーデン等の研究所が参加した。検証には 2つの方法が用いられた。一つは標準問題によるモデル間 の相互比較で, 款類の収穫30日前に空気中に HTOが 1 時 間存在した時の, 土䖯中 HTO濃度, 植物中HTO とOBT 濃 度等の時間変化が比較された ${ }^{(13)}$ 。もう一つは実験データ との比較で，小麦にHTOをばく露した時のOBT生成に関 する実験デー夕等が用いられた(14)。前者については，最 も単純な表層土壤中濃度の結果においてさえも約 1 析の違 いが見られた。後者のOBT生成については夜間にばく露 した場合に実験値よりひ小さく予測した結果が多かった。 特に，夜間にOBT生成がないと仮定したモデルではその 傾向が大きくなることが明らかになった。

このようなモデル恰恠のための国際協力は，現在は IAEAが主催するBIOMASS計画として進められている。 トリチゥムむ重要な核種として取り上げられており, 今の ところ日本からは原研が参加している。

\section{5. パラメータ}

これらのコード開発と同時に，奏際の計算のためには 種々のパラメータを整備しておく必要がある。トリチゥム の環境中移行パラメータとしては、空种中 HTおよび HTOの土㙵への沈着速度や大気への再放出速度、OBT生 成割合, 降水洗浄係数などが重要と考えられる。また，モ デルによってはHTOの場合, 大気一土壤間あるいは大気一 植物間の交換速度で表わされる場合がある。HTの土壌へ の沛着速度はこれまでさまざまな条俳下で測定されている が，日本での測定值はほとんどない。HTの土㙗への沈着 速度はかなり広い範国に分布している上，サイトの土質や 気象条件等に依存する可能性が高い。したがって,サイト での值をあらかじめ測定することも重要と考えられる。 OBT の生成についても植物に大きく依存するので, 評価 対象植物ごとの生成割合のデータが必要である。 その他のパラメータとしては，平常運転時の線量評価に 
関係する農産物や畜産物の水洗や調理に伴うトリチウムの 除染係数が重要である。我が国では玄米や大豆などについ て調べられた例はあるが(15)，その情報は限られている。

\section{一参考文献一}

(1) Raskob, W. : KfK 4605, (1990).

(2) Raskob, W. : KfK 5194, (1993).

(3) Russel, S. B., Ogram, G. L. : Fusion Technol., 21, 645 (1992).

(4) Murata, M., Noguchi, H. : Proc. 3rd Int. Symp. on Advanced Nuclear Energy Research-Global Environment and Nuclear Energy, Mar.13-15, Mito, Japan, p. 104 108 (1991).

(5) 原研保健物理部等：JAERI-Review 95-020, p. 245～246 (1995).

(6) Raskob, W. : FZKA 5512, (1995).

(7) 原子力安全委員会 : 「発電用原子炉施設の安全解析に関する 気象指針」，(昭和57年1月28日決定).

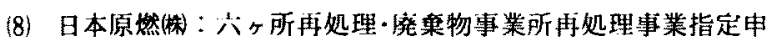
請書, (1993年 3 月).

(9) Raskob, W., Barry, P. : J. Environ. Radioact., 36, 237 (1997).

(10) Raskob. W. : KfK 5364, (1994).

(11) Neil, B. C. J. : HSD-ST-91-21, (1991).

12. IAEA : "Technical Basis for the ITER Interim Design Report, Cost Review and Safety Analysis", ITER EDA Documentation Ser., No.7, (1996).

(13) Working Group of the BIOMOVS II : "Tritium in the Food Chain", BIOMOVS II Tech. Rep., No. 8, (1996)

(14) Working Group of the BIOMOVS II : "Tritium in the Food Chain", BIOMOVS II Tech. Rep., No.13.(1996).

(15) 新井清彦: NIRS-R-14, p. 21 26 (1987).

\section{V. 安全管理とモニタリング}

\section{V-1 安全取扱技術}

日本原子力研究所 大平 茂*, 林 巧*

\section{1.トリチウム閉じ込め·除去}

トリチゥムは，他の放射性物質に比較して，(1)漏洩し やすい，(2)高温で金属をす透過する，(3)漏洩・透過したト リチウムの空間内の搪散速度が早い等, 閉じ込めが難しい 核種である。また，核融合炉では多様な化学形で，広範团 の機器·施設に分布する。よって, トリチウムを安全に取 り扱うには，(1)存在化学形，量，分布を的確に把握し，(2) 限定された空間に閉じ込めるへく障壁を多重に設け，(3) たとえ漏洩・透過しても，トリチウムを迅速に検知，隔離 し，(4)効率よく除去することが重要となる。

\section{(1) 多重隔壁格納}

大量トリチゥム取扱い施設では, 多重隔壁格納の考えを 採用し、作業員のトリチウム被ばくを防止し，周辺環境へ のトリチゥム放出低減化を四る。第 V-1 表に主要なトリ チウム取扱い施設の閉じ込め概念を整理したが, 多重の考

- Shigeru O'HIRA, Takumi HAYASHI, Japan At. Energy Res. Inst.
え方や適用範囲に多少差異があるもののITERを含めほぼ 同様である(1) (4)。第 V-1 図に，わが国唯一のグラムレベ ルのトリチウムを取り扱元る研究施設：原研トリチウムフ 口セ石研究棟 (TPL, トリチウム許可量：眝蔵量 $60 \mathrm{~g} \cdot 1$ 日 最大使用数量 $25 \mathrm{~g}$ ，実貯蔵量 $47 \mathrm{~g}(1997$ 年 3 月現在))におけ る閉じ込め概念図を示す。以下，TPLの概念を参照しつ つ安全閉じ込め技術開発の現状を紹介する。

\section{(2) 第 1 次閉じ込め系}

核融合炉では, 真空容器, 燃料循環系(排気, 精製, 同位体 分離, 眝蔵, 供給等), 堌殖ブランケット系等に相当する。こ こでは，(1) 十分な気密設計 $\left(<10^{-6} \mathrm{Acc} / \mathrm{s}=<10^{-6} \mathrm{~atm}\right.$ ・ $\mathrm{cc} / \mathrm{s} \doteqdot<10^{-6} \cdot 10^{5} \mathrm{~Pa} \cdot 10^{-6} \mathrm{~m}^{3} / \mathrm{s}=10^{-7} \mathrm{~Pa} \cdot \mathrm{m}^{3} / \mathrm{s}$ in TPL), (2)取り扱うトリチゥムの化学形, 状態に対応した隔離弁, 安全機能(圧力逃がしタンク他)の設置, (3)各装固·系統ご とのトリチゥム荲の制限(ITERでは $100 \mathrm{~g}$ 程度)が重要で ある。

\section{（3）第 2 次閉じ込め系}

第 1 次系の装固配管等を収納するグローブボックス（以 下 GB)，GB 中に漏洩・透過したトリチウムの除去設備 (GPS)，各種の排出ガス中のトリチウムの除去設備(ERS) 等加ら構成される。基本的に，(1)平常時および 1 次系機 器の異常時に作業環境へのトリチウム透過·漏洩量を管理 基準値以下にできること，(2) 1 次系装置異常時に火災・爆 発等の発生を防止できること, 等が要求される。このた め, GBは(1)気密設計 $\left(<0.1 \mathrm{vol} \% / \mathrm{h}\right.$ at $-100 \mathrm{mmH}_{2} \mathrm{O}$ in TPL) とし, (2)常時負圧維持 $\left(0 \sim-40 \mathrm{mmH}_{2} \mathrm{O}\right.$ in TPL) お よびトリチゥム濃度監視し，(3)水素爆発防止のため不活性 ガス(室素等)雾囲気で, 酸素濃度監視 $(<2,000 \mathrm{ppm}$ in TPL)する。

ERSは，様々なトリチウム排ガスを貴金属触媒反応器 $\left(500^{\circ} \mathrm{C}, \mathrm{Pt} / \mathrm{Pd}\right.$ 等)て酸化し，HTOを乾燥塔で吸着除去す る。反応器および乾燥塔を各 2 段直列に配置し, 高いトリ チウム除染係数 (DF：10 程度 in TPL) 確保する。GPS 屯。同様の触媒酸化 $\left(200^{\circ} \mathrm{C}\right)-$ 水分吸着方式で, GB䨌囲気 を常時連続循環し除染する。諸外国では，高温活性金属 ベッド等でトリチゥム成分を分解除去する方式あある。

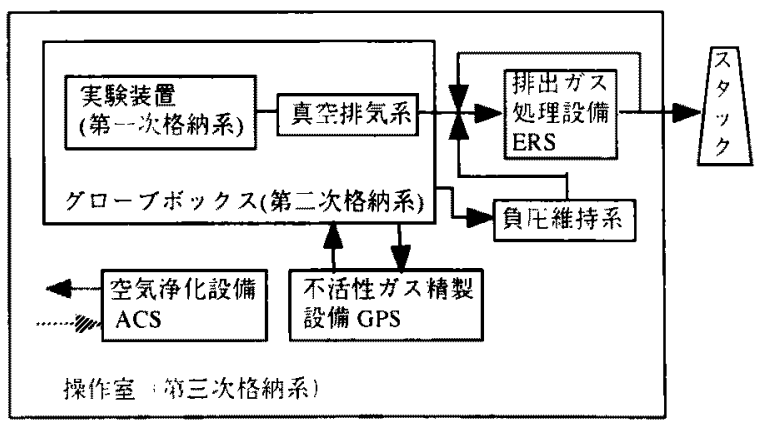

第V-1図 TPLにおけるトリチウム三重隔壁格納システム 概念図 


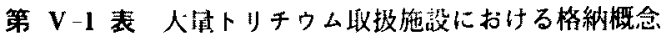

\begin{tabular}{|c|c|c|c|c|c|c|}
\hline 国(研究所) & 日本(原研) & 米国(LANL) & ドイッ (FZK) & イタリ 7 (ISPRA) & 米国(PPPL) & 国祭共同 \\
\hline 施設の名称 & TPL & TSTA & TLK & ETHEL & TFTR & ITER \\
\hline トリキゥム眝蔵許可量 (g) & 60 & 200 & 40 & 100 & 5 & 数 $\mathrm{kg}$ \\
\hline トリチウム眝蔵箸(g) & 47 & $\sim 100$ & 22 & $<1$ & $<5$ (夷験時) & - \\
\hline 格納隔壁数 & 3 & 3 & 3 & 3 & 3 & 3 \\
\hline 1 次系用除去設備 & パッ升処理 & パッチ姏理 & ハッチ処理 & バッ千好理 & バッチ㚮理 & バッチ処理 \\
\hline 2 次系用除去設備 & 連続好理 & バッチ処理 & 連㸿処理 & 連続処理 & 連続処理 & 連続好理 \\
\hline 負压維持 $\left(\mathrm{mmH}_{2} \mathrm{O}\right)$ & $-15 \sim-25$ & $\sim-20$ & $\sim-55$ & $\sim-25$ & $\sim-20$ & $\sim-25$ \\
\hline 換気回数/毎時 & 3 & - & 5 & 10 & 3 & 1 \\
\hline 3 次系用除去設備 & ハッッ処理 & パッチ姏理 & なL & なし & バッチ好理 & バッ千処理 \\
\hline $\begin{array}{l}3 \text { 次系のトリチゥム濃度が } \\
\text { 上昇した時の対応 }\end{array}$ & $\begin{array}{l}3 \text { 次系用除去 } \\
\text { 起動 }\end{array}$ & $\begin{array}{l}3 \text { 次系用除去 } \\
\text { 起動 }\end{array}$ & $\begin{array}{l}1 \text { 次 } 2 \text { 次飞 } \\
\text { 対庒 }\end{array}$ & 換気回数堌 & $\begin{array}{l}3 \text { 次系用除去 } \\
\text { 起動 }\end{array}$ & $\begin{array}{l}3 \text { 次系用除去 } \\
\text { 起動 }\end{array}$ \\
\hline
\end{tabular}

\section{（4）第 3 次䦙じ込め系}

異常時に作業環境に放出されたトリチウムを閉じ込める 大型気密室 $\left(1 \mathrm{vol} \% / \mathrm{h}\right.$ at $\left.-15 \mathrm{~mm} \mathrm{H}_{2} \mathrm{O}\right)$ とトリチウム除去 設備(ACS)で構成される。通常は，空調換気系により負 压制御 (-5〜 - $\left.15 \mathrm{mmH}_{2} \mathrm{O}\right)$ するが, トリチウム濃度異常 時は，空調換気系の緊急遮断弁汃閉止し，翼常区域のみ $\operatorname{ACS}\left(\right.$ 触媒酸化 $\left(200^{\circ} \mathrm{C}\right)$-水分吸着方式)でトリチウムを循 環除去する。さらに，一部ガスをERSを介して排出して 負压を維持し，可能な限り周辺環境へのトリチウム放出を 低减する。

第 3 次閉じ込め系用に独立した除去設備のない施設(第 $\mathrm{V}-1$ 表参照) あるるが, ITERではTPLと同様，2段の除 去設備で対応(循環除去・負圧維持)する。また，迅速にト リチゥム除去するため，閉じ込め系容積を一定值以下 (ITERで約 $10,000 \mathrm{~m}^{3}$ 以下 $\left.{ }^{(4)}\right)$ に分割する設計となる。

$\operatorname{ACS}$ 惊，点検保守作業時にもトリチゥム除去機能をむ つ局所排気系として有用である。原研では現在，長時間連 続除去運転や大規模閉じ込め系の除去設備として，気体分 離膜方式を開発している(5)。本方式では，トリチウム污染 ガスを分離膜を介して话環し，膜を選択的に透過するトリ チゥム成分 (HT, HTO)を濃縮，大量湿分を直接凝縮除去 する。減容濃縮污染ガスは最終的に小型の触媒酸化-水分 吸着塔でトリチウム除去し，トリチウム除去設備の小型効 率化を区る。

\section{（5）安全運転実續}

上述の多重閉じ込め系により数 10 数 $100 \mathrm{~g}$ 規模のトリ チウムは各国(第 V-1 表)で安全に取り扱われている。日 本(原研)では, グラムレベルのトリチウム取报い開始 （1988年 3 月）から現在まで，作業員の被ばくや，作業環境 および周辺環境へのトリチウムの異常漏洩および放出はな い。トリチゥム閉じ込め実績では，年平均排出量で 0.15 $\mathrm{Ci} / \mathrm{yr}$ 以下(諸外国の同等施設の垁績の50～100分の 1)， 排父氞口濃度 ( 3 力月平均值)で HTO の濃度基準 $\left(5 \times 10^{-3}\right.$ $\mathrm{Bq} / \mathrm{cm}^{3}$ )の約 $1 / 200$ 以下が維持できている(6)。

さらに，原研では，日本で林経験のトリチウムの異常泚 洩時の安全閉じ込め性能をも実証するため, TPL内に模
擬試験装置の設置を進めている。

\section{2.トリチウムの輸送}

核融合㶰の燃料としてのトリチウムを輸送する場合に は, 数 $100 \mathrm{~g}$ 単位の大量のトリチウムを 1 回に輸送すること になる。これは，我が国の安全規制で定められている放射 性輸送物(輸送容器に核然料物質あるいはその他の放射性 物質が収納された状態のもの)の区分からいうと， B 型輸 送物となる。他の区行の輸送物 (L型，IP型およびA型)で は，輸送中に過酷な事故に遭遇し，万一，収納物の漏洩が 生じた場合でも一般公衆の被ばくが線量当量限度を超えな いよう，輸送放射能量等を制限するが， B 型輸送物では， 輸送容器自体で安全性を担保する。よって, 過酷な事故条 件に十分に耐えられる極めて頑义なものが要求される。

放射性同位元素等に上る放射線障害の防止に関する法律 の施行規則においては，最小寸法,輸送中に予想される温 度变化, 振動等に耐える強度, 輸送物の線量当量率の限度が 定められており，L型を除き通常の輸送において遭遇する 可能性のある状態を想定した試験条件による試験後です, 輸送物の線量当量率, 密封性能および表面污染密度につい て一定の要件を満足することが要求される。

B型輸送物に対しては，さらに輸送中過酷な事故に遭遇 しても十分に耐えられる能力を実証することが要求され る。このため, 高さ $9 \mathrm{~m}$ からの落下試験, $800^{\circ} \mathrm{C} \cdot 30 \mathrm{~min}$ 間 の酎火試験, 水深 $15 \mathrm{~m}$ での浸清試験等の「特別の試験条件」 が追加して課せられ, 試験終了後翰送物の線量当量率, 密 封性能抢よび表面污染樒度等について一定の要件を満足す ることが要求されている。

現在, トリチウムの国際間輸送のための世界最大の輸送 器器は，原研で開発した水素吸蔵 $Z r-C o$ 合金を用いた輸 送容器 $\left(25 \mathrm{~g} \mathrm{~T}_{2}\right)$ である。トリチウムはその $\beta$ 崩壊により 発熱 $(1 \mathrm{~g}$ で約 $0.3 \mathrm{~W})$ するので，将来のより大型の輸送容 器の開発においては, 容器内部に収納される金属水素( リチウム)化物の熱平衡を保つための崩壊熱の外部への放 散と, 耐火条件(外部からの断熱)をいかにバランスさせる かが技術的な課題となる。 
ITER国内誘致に向けて, 初装荷や運転中に必要な大量 のトリチウムの安定確保は重要課題であるが，国際間輸送 については，過去の原研による輸送の実績などから見て， 様々な特別な制約が課せられることが予想される。このた め, 供給可能量, 1 回当たりの可能輸送量および輸送回 数,必要量備蓄に要する期間,核物質防護の適用状況, 管理 方法等の経済的, 技術的諸因子について十分検討し，対応 していく必要がある。

\section{一参考文献一}

(1) Naruse, Y., et al. : Fusion Eng. Des., 12, 293 (1990).

(2) Anderson, J. L., et al. : TSTA-SAR, (1982).

(3) Schira, P., et al. : Fusion Eng. Des., 18, 19 (1991).

(4) ITER-DDD : Tritium Plant, WBS3.2 (1996)

(5) Hayashi, T., et al. : 4th Int. Symp. on Fus. Nucl. Technol., Tokyo, Japan, 1997, To be published in Fusion Eng. Des.

(6) Yamada, M., et al. : Fusion Technol., 28, 1376 (1995).

\section{V-2 廃棄物管理および処理技術}

\section{日本原子力研究所 大平 茂, 林 巧}

ITER 等の大規模トリチウム取扱い施設や製造施設等に おいては，各種材料へのトリチウムの吸着・溶解·拡散等に より設備, 機器が污染され，その一部あるいは全部が, 交

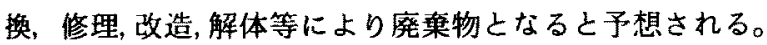
トリチゥムは, ガス(HT, DT, T 2 ), 水(HTO, DTO, $\left.\mathrm{T}_{2} \mathrm{O}\right)$ あ るいは有機物と廃较物中に様々な化学的状態で存在するた め、取扱い上の難しさを抱えている。また，廃率の対象と

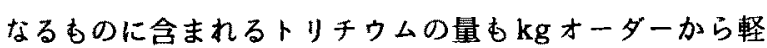
微な污染に至るまで，かなり幅があり，また，放射化生成 核種との複合的な污染があるなど污染の程度, 状況に応じ た管理，処理·処分が求められる。トリチウムに関する安全 性の見地から，対象となる設備・機器の全部あるいは一部 を廃棄物として最終的に好分可能な形にするまでには，次 のようなことが重要となると思われる。

(1) 作業環境や外部環境へトリチウムが放出されるリス クの低減の観点から，廃棄する対象となる設備, 機器 のトリチウムの残留量を交換, 解体等の作業の前にで きるだけ減少させること。

（2）交換，解体等の作業中における作業環境および周辺 環境へのトリチウムの放出を低減すること。

（3）処理前の保管，運搬中の廃率物加らのトリチウムの 漏出を低減すること。

(4) 切削, 切断, 圧縮等の機械的処理工程での污染拨大を 防止すること。

(5) ALARAの精神に基づき適切な好理により，処分さ れる廃衰物中のトリチウム濃度を十分下げること。

(1)は、いわゆるオンラインでの除染であり，この工程 でできるだけトリチウムの滞留量を減らすことが，後の工：
程での安全確保のための負担の軽減になるとともに，トリ チウムの再利用という観点からあ重要である。例えば, プ ラズマ対向機器や，燃料精製系の触媒等高度に污染した機 器ではできるだけ, 交換, 解体等の作業の前に, ブラズマ 洗浄 $^{(1)}$ ，水素同位体ガスパージ(2)，加熱脱離 ${ }^{(3)}$ 等によりトリ チウムを材料から追い出すことが考えられ，実際，JET 等であ試みられている(4)(5)。見在ITER工学設計活動等に おいてむトリチゥム滞留量の更なる低減の具体的方法が検 討されている。

(2) は, 交換, 解体等の作業におけるトリチウムの閉込・ 除去が要点であり，作業空間の適切な隔離，除去系への接 続等が行われれば問題はない。

(3)は，特にトリチウムで高度に污染した物について, 処理までの間の保管や運搬に当たってトリチウムが吸着・ 溶解している材料からの再放出があることから，これを閉 込め，除去する必要が出てくる，具体的には廃童物そのも のを覆ってしまうような容器あるいは部屋のようなすのが あれば允分だが，放射化した機器では遠隔操作や，放射線 遮蔽を考虑する必要がある。

(4)は，ダイバーターカセットのようなヒートシンク材と アーマー材が結合している複合材料機器, ブランケットの ような複雑な構造を持った機器では, どうしてもその大き さや構造から好理するために切断, 材質による弁別等の作 業をせざるを得ない。その場合の切断はなるべく2 次的な 廃棄物(切りカスとか潤滑油等)が出ない方が望ましい。こ のための技術としては原子炬施設における大型機器の交換 や解体等が参考となると思われる。

(5)は, いわゆるオフラインの除染であり, 最終的な好分 のためのトリチゥム濃度の基準值を満たすまでにトリチウ ム濃度を下げるための工程である。これについては, 軽微 な污染除去のための拭き取り，洗浄から，水素ガス，水蒸気 パージによる除染, 加熱脱離, エッチング(6), プラズマ放電 洗浄、レーザー脱離 ${ }^{(7)}$, 紫外線照射 ${ }^{(8)}$, 溶解・焼却といった 様々な方法が研究開発されており，いくつかがJET等で あ採用されている。ITERの設計では，トリチウムの滞留 量が多い廃集物については加熱脱離を行いトリチウムを回 収することが考えられている。この工程でも当然ながら放 射化した機器では遠隔操作や，放射線遮蔽を考慮する必要 がある。また，トリチウムの污染が低いものであっても， かえって除染をすることにより2次的な廃菓物(紙, ダス 卜，油，水)を生成してしまうヶースも考えられ，その工程 を最適化する必要がある。

いずれにせよ，トリチウムは水素状であっても環境中で の様々な触媒作用により大部分が水の形となり，冬種材料 表面に容易に付着し，その後材料中へ㹡散・溶解したり， 表面から脱離・再放出するなよ゙，複雑な挙動をする。トリ チウムを使用した機器からトリチウムを100\%除去するの は困難ではあるが，材料の稞類(金属，セラミックス，有機 材料, コンクリート)や污染した表面の性質, トリチウムの 
化学形等を把握し，効果的な除染方法を選択することによ り，十分低いレベルまで除染を行うことは難しいことでは ない。放射化した機器では遠隔操作や，放射線遮蔽を考虑 する必要があるが，例えばホットセル内での遠隔操作や遮 蔽の技術的な蓄積はあるのでそれほど困難ではないと予想 される。

\section{一参考文献一}

(1) Antoniazzi, A. B., et al. : Fusion Technol., 21, 867 (1992).

(2) Nishikawa, M., et al. : Fusion Technol., 21, 878 (1992).

(3) Krasznai, J. P., et al. : Ontario Hydro Res. Div. Rep. 90-199 $-\mathrm{K},(1990)$.

(4) The JET Team : Fusion Eng. Des., 22, 77 (1993).

(5) Saibene, G., et al. : Fusion Eng. Des., 22, 133 (1993).

(6) Hirabayashi, T., et al.: J. Nucl. Matel., 136, 179 (1985).

17) Rodorigo, L., et al. : Fusion Technol., 28, 940 (1995).

(8) Krasznai. J. P., et al. : Fusion Technol., 28, 1336 (1995)

\section{$\mathrm{V}-3$ 施設内モニタリング技術}

\section{核融合科学研究所 佐久間 洋一*}

施設内の作業環境中トリチウムモニタリングに関する最 新技術の現状を紹介する。主に空気中トリチウムのモ二タ リングについて述べるが，表面污染と水モニタについても 簡単に言及する。

\section{1. 空気中トリチゥムのモニタリング}

トリチウムの環境空気中モニタリング技術は，確立して いるといってもよいほどこの10数年間ほとんど変わってい ない(1)(2)。それは從来の技術で, 法に定める管理基準を満 たす測定ができるということが主な理由である。室内空気 は電離箱, 排出空気は比例計数管あるいは水蒸気透過膜式 電離箱で十分な測定ができる。さらに，液体シンチレー ション測定法を用いれば時間的な遅れは出るすのの，バッ クグラウンドレベルまでの測定が可能である。法定濃度限 度は，第 V-2 表に示すように，水蒸利状と分子状(法律で は「元菜状」となっている)では大きな差がある。人体に対 する影響が大きい水蒸気状のトリチゥム(HTO)が，より 厳しく規制されている。また，排出空気の規制値は 3 ヶ月 の平均值ではあるが，かなり厳しくなっている。

それでは何の問題もないかというとそうとはいえない。 トリチウムとラドン，HTOと分子状トリチウム(HT)の升 別測定か問題となることがある。核触合実駼施設において

\begin{tabular}{|c|c|c|}
\hline & 分子状 & 水蒸笑状 \\
\hline 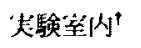 & $2.0 \times 10^{10}$ & $7.0 \times 10^{5}$ \\
\hline 排出空気 ${ }^{\dagger \dagger}$ & $9.0 \times 10^{7}$ & $5.0 \times 10^{3}$ \\
\hline
\end{tabular}

'8hの均值, "3r月間の平坛值

* Yoichi SAKUMA. Natl. Inst. for Fusion Sci.

はこのほかに，中性子線や X線, 電磁場, ${ }^{41} \mathrm{Ar}$ 等の気体状放 射化牛成物の影響をも考虑する必要がある。トリチウムを 吸着した数 $\mu \mathrm{m}$ 程度の小さな金属粒子が，大きな内部被ば くを引き起こすことがあるが、ほとんよ゙研究が行われてい ないとの報告むある(3)。ラドンはトリチウムのモニタリン グが始まって以来, 常に厄介者である。実験室の換気を止 めると計数值が上昇して, 夜間に警報が鳴り出すことか 間々ある。また，排気を基準值まで测定しようとすれば， ラドンを除いた測定をしなければ通常は測定できない。核 融合実駼施設における ${ }^{41} \mathrm{Ar}$ 等の放射化生成物む同様であ る。HTO とHT の并別は常に必要とされる訳ではなく, 測定されるトリチウムをすべてHTOとして安全側に解釈 している場合が多い。しかし，その手法では規制値を越え てしまう場合にはそれらの個別の濃度を求める必要があ る。前述した水祭父透過膜方式の電離箱ではHTOだけを 测定できる。水蒸気を除いた後でHTを酸化して測定すれ ば両者を弁別測定できる。比例計数管と水蒸気透過膜を組 み合わせても可能である。強い電磁場が測定に影響する場 合には，装置を離れた場所に置いて空気を送って測定すれ ば解決できる。

このように，見在のトリチゥムのモニタリング法はすべ て放射線を測定する方法である。大量のトリチウム測定で は, 重量測定やレーザーラマン法などの物理暒測定も用い られている。モニタリングにも、レーザー光やマイクロ波 の吸収スペクトルを利用した方式などいくつか研究されて いるが，まだ実用化には至っていない。

\section{(1) 通気式電離箱}

最すよく用いられている方式でトリチウム取扱い施設の 室内モニタは，はとんどのこの方式である。取り扱い易 く，洒格も比較的安い。問題は，ラドン等の放射能を同時 に测ってしまうこと，HTOとHTを弁別できないことで ある。 線の影響は逆同時計測によって取り除くことがで きる。検出限度は機種によって異なるが，市販の最る性能 の良いもので $2 \times 10^{4} \mathrm{~Bq} / \mathrm{m}^{3}$ 程度である。

\section{（2）水蒸気透過膜式電離程}

特長はラドンの影響を取り除き，HTOをHT等から弁 別して測定できることにある。水蒸気を選択的に透過させ る性質を持った高分子材料(水蒸気透過膜)を細い管状にし たもの(中空系)を多数束好て用いている。これは本来，乾 燥空気を造るために開発されたるのである。その水蒸気に 対する性暂を利用して，空気中の水蒸気げけを集めてその トリチゥム濃度を計測する。1 次側に測定対象の空気を流 し，2次侧(透過侧)には窒素を用いる。この 2 次側の気体 を通気式電離箱に通せば，空気中の水蒸気に含まれるトリ チゥム濃度を測定することができる。ただし，HTOが膜 を透過するのに要する時間の遅れがある。2次側の気体は 除湿して循環させて用いる。その時わずかに透過するラド ンが次第に蓄積するので少しずつ窒素を交換する。HTの 測定が必要ならば，ラドンを除去するため，触媒による酸 
第 V-3 表 各種湘定法の比較

\begin{tabular}{|c|c|c|c|c|}
\hline 測定法 & Rnの升別 & HTとHTOの弁別 & 検出限界 $\left(\mathrm{Bq} / \mathrm{m}^{3}-\mathrm{air}\right)$ & リアルタイム測定 \\
\hline 通気式電離箱 & 不可 & 不可 & $2 \times 10^{4}$ & 可 \\
\hline 水蒸気透過膜式 & 可 & 可 & $4 \times 10^{3}$ & 可 \\
\hline 電離箱 & & & & 僅かな遅れ \\
\hline 比例計数管 & 可 & 不可 & $2 \times 10^{3}$ & 可 \\
\hline $\begin{array}{l}\text { 㿰体シンチレーション } \\
\text { 検出器 }\end{array}$ & 可 & $\begin{array}{c}\text { 可 } \\
\text { Hンプリング法 }\end{array}$ & バックグラウンドまで & 不可 \\
\hline 检出器 & & サンプリング法 & & \\
\hline
\end{tabular}

'水蒸気透過膜と併用すれぱ可能

化後，あう一度同様の操作をすることにより弁別测定でき る。名古屋大学工学部のトリチウム取扱い施設のもので, HTOの検出限界はおよそ $4 \times 10^{3} \mathrm{~Bq} / \mathrm{m}^{3}$, 交換に必要な窒

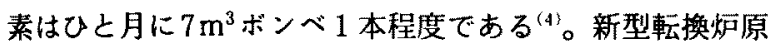
型炉ふふげん」のモニタにも用いられている。

\section{(3) 比例計数管}

最大の特長は，エネルギー弁別によってラドン等の放射 能の影響を取り除いて，トリチウムだけを測定できること である。 線の影響は逆同時計数によって取り除くことが できる。HTOとHTとの弁別はそのままではできないが， 水蒸気透過膜を併用すれば可能である。計数ガスとして通 常メタンを用いるので，室内で使用するには排気の処理が 必要となる。したがって，排気モ二タとして用いられる。 核融合科学研究所のトリチウム取扱い施設の排気モニタで は, 険出限界は $2 \times 10^{3} \mathrm{Bg} / \mathrm{m}^{3}$ 程度である。

（4）棭体シンチレーション計測法

実時間測定はできないが最も精度と感度の高い計測法で ある。環境トリチウムの测定はほとんどこの方式で行われ ている。空気中のHTO, HT, $\mathrm{CH}_{3}$ Tを分けて採集すればそ れらの弁別湘定ができる。時間的に遅れること，採集期間 中の平均濃度しか湘定できないことから他のモ二夕装置と 併用される。検出限度は，試料の採集量や採集後の処理な どによって異なるが，バックグラウンドレベルまで測定で きる。

この方法のひとつとして，簡易空気中トリチウム水捕集 器の開発が行われている(5)。これは $45 \mathrm{~mm} \phi \times 50 \mathrm{~mm}$ の円 筒形のプラスチック容器に塩化カルシウムを入れ，湘定対 象筒所で盖を開けて数週間放置して空気中の水蒸気を集め る。同時に自記記録計によってその間の温湿度を記録して おく。採集した水を塩化カルシウムごよ液体シンチレー ションカゥンタで測定し，测定対象期間中の温湿度から空 気中トリチゥム濃度を求める。検出限界は $3 \times 10^{2} \mathrm{~Bq} / \mathrm{m}^{3}$ 䑶度と報告されている。絶対湿度やシンチレーションカウ ンタの性能, シンチレータの種類に依存するものの, その 期間中の平均水蒸気状トリチゥム濃度だけを簡便に測定で きる。

\section{2.その他のモニタリング}

\section{（1）表面污染モニタリング}

現在,トリチウムによる表面污染のモニタリングは，主
としてスミア法か超薄膜大面積ガスフローカウンタによる 測定で行われている。スミア法では，拭き取った沪紙を $2 \pi$ フローカウンタか液体シンチレーションカウンタで計 測する。沪紙のトリチゥム測定はかなり高感度かつ高精度 で行える。しかし，拭取り率は推定する他になく時間的な 遅れる大きい。超薄膜大面積ガスフローカウンタは簡便で 拭取り率の推測の問題はない。検出限界は機種によるが $1 \times 10^{4} \mathrm{~Bq} / \mathrm{m}^{2}$ 程度である。

オンタリオハイドロのケラーニらは，表面のトリチウム の $\beta$ 線が空気を電離する量を測定して、トリチウム量を 求める方法を報告している(6)。まだ市販されるまでには 至っていないが，平面の污染検査には有望な方法である。 また，原研の金子らは光検出用PINフォトダイオードを 使ったトリチウムモニタの開発を報告している。このダイ オードは，可視光を検出するむのであるからトリチウムモ ニタとして用いるには，遮光しなければならない。検出限 度はその遮光フィルムによって変わり，フィルムがなけれ ば $1.4 \times 10^{3} \mathrm{~Bq} / \mathrm{m}^{3}$ 程度まで測れる(7)。 $\mathrm{PbI}_{2}$ 半導体検出器 によるトリチウムピーク検出の報告もあり，トリチウムモ ニタとしての応用も期待できる ${ }^{(8)}$ 。

\section{（2）排水モニタリング}

1989年 5 月の法令改正により，トリチウムの排水濃度限 度は従来の約 $1 / 2$ の $6 \times 10^{7} \mathrm{Bg} / \mathrm{m}^{3}$ となった。その他の核 種の濃度限度む引き下げられたので, 排水モ二タとして自 動の液体シンチレータ方式が開発された。したがって, 従 来主に用いられていたプラスチックシンチレータ方式に比 べて，非常に感度も精度も良くなった。現在製品化されて いる装置の検出限界は，10分間測定で $0.3 \times 10^{6} \mathrm{~Bq} / \mathrm{m}^{3}$ で ある。

\section{一参考文蕀一}

(1) 奥野健二：プラズマ・核融合誌, 72, 1376 (1996).

(2) 日本アイントーブ協会理工学部会放射線防護機器専門委編： 放射線防灌用設徣・機器力゙イド 1996/97 年版, (1996).

(3) McConville, G. T., et al. : Fusion Technol., 28, 905(1995).

(4) Yamamoto, I., et al. : J. Nucl. Sci. Technol., 25, 289, (1988)

（5）中司 等, 他：保健物理学会第32回研究発表会, (1997).

(6) Kherani, N. P, Shmayda, W. T. : Fusion Technol., 28, 893 (1995)

（7）金子記一，他：分子科学研技術研堆，15，108（1996）.

(8) Shah, K. S., et al. : Nucl. Instrum. Methods., A380, 266 (1996) 


\section{$\mathrm{V}-4$ 環境中モニタリング技術}

九州大学 岡 井富 雄*

環境モニタリングの試料としては主に犬然水,生物およ び大気が調査対象となる。これらの環境試料はそれぞれ適 切な処理により，測定に適した化学形(ほとんどが水)に変 換されている。トリチゥムの測定には，多数の試料を簡便 に処理できることから，見在では低バックグラウンド仕様 の液体シンチレーション(液シン)計数装置が最も一般的に 使用されている。このほかに, 液シン法とは測定原理が異 なるへリウム同位体法も行われている。ここでは,トリチ ウム測定のための試料の採取・処理法および試料調製法等 環境中モニタリング技術について現状を述べる。

\section{1. 環境試料の操取および処理}

\section{（1）天然水}

天然水は，雨水，河川水，湖水，地下水および海水が主に 測定対象となる。採取した試料には不純物や有機物等が含 まれているので，蒸留を行って試料水を精製する必要があ る。

\section{（2）生 物}

生物試料に含まれるトリチウムは，組織自由水トリチウ ム(TFWT) とOBTに大別され，OBTはトリチウムの生体 分子への結合の強さの違いによって, 交換可能型OBT と 非交換型OBTに分類される。交換可能型OBTは，水と接 触させておくと容易に水素と固換されてしまうので, OBT を分析する場合には試料の取扱いに注意が必要であ る。

TFWT の回収には, 真空東結乾嬠法や共沸蒸留法(1) 用いられている。真空涷結乾燥法はゆるやかにTFWTを 回收できるので，最す広く利用されているが，回收水に低 沸点の有機物を含むことが多いので，酸化剂を加えて蒸留 する必要がある。共沸蒸留法はベンゼンやトルエンなどの 有機溶媒之生物試料の混合試料を蒸留し, 有機溶媒之 TFWT の共沸混合物を回收する方法である。ベンゼンや トルェンは優れたシンチレータ溶媒なので，共沸混合物が そのまま䘸シン用の試料となるのが利点である。

しかし，低濃度の試料の場合には，回收した試料水につ いてトリチゥム濃縮を行う必要も生じてくるので，現在の 環境モニタリングには水の形で回収する真空凍結乾燥法の 方が有利であろう。

OBT は，TFWTを回收した後の乾燥試料を燃烧装置を 用いて燃烧し，水として回収する。環境試料の OBTを精 度よく分析するためには，かなり大量の試料を燃焼する必 要があるので，専用の燃烧装置が必要となる。第 V-2 図 に九州大学で考案された燃焼装置を示す ${ }^{(2)}$ 。内径 $5 \mathrm{~cm}$, 長

* Tomio OKAI, Kyushu Univ.

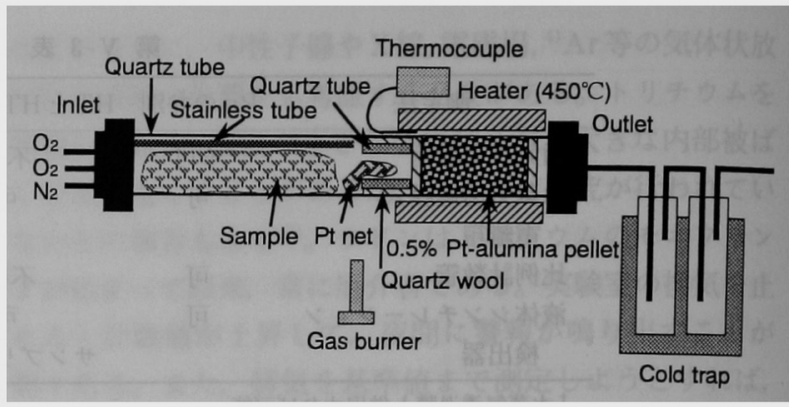

第 V-2 図 生物試料燃焼装置 ${ }^{(2)}$

さ $100 \mathrm{~cm}$ の透明石英管の両側に真鍮製のフランジを備え ており, 最大 $150 \mathrm{~g}$ の乾燥試料を燃焼することが可能であ る。本装置は不完全燃焼をできるだけ少なくするために， 燃焼管後部には白金ネットと0.5\%白金・アルミナペレット 触媒を用い，また燃焼効率を高めるために，酸素ガスを試 料の部分と白金ネットの部分にそれぞれ供給する等の工夫 がされている。このほか, 高速燃焼装置(Oxygen Bomb) あ用いられている。これはステンレス鋼製の燃焼チェン バーに乾燥試料と酸素を 20 気圧の高圧で封入し, 電気着火 で短時間に燃焼する方法である。内容量 $1.85 l$ のチェン バーを用いると $10 \mathrm{~g}$ までの乾燥試料が燃焼でき， $5 \sim 6 \mathrm{ml}$ の燃哑水を得ることができる。高温で試料燃焼を行った場 合には，燃焼水に有機物かかなり混入するので，酸化剤を 加えて蒸留を数回行い試料を精製する必要がある。

これに対し，高周波誘導により発生させた酸素プラスマ を用いて，生物試料を低温で灰化(燃焼)する方法(3)(4)が行 われている。この方法の特長は, 低温で武料を燃焼できる ので然燒水の純度が高く, 蒸留を 1 回行うだけで蒸留水と 同じ純度が得られることや, 無人運転が可能なことなど, 触媒を用いた高温燃烧法に比べて簡便なことである。

（3）大 気

人'x仲には，HTO，HTおよび炭化水素(メタン以外の気 体の存在量は少ないので,メタンで代表できる。以下， $\mathrm{CH}_{3} \mathrm{~T}$ の化学形でトリチウムが存在している。

HTOの捕集法は，コールドトラップ法之吸着法があり, 前法では除湿器を用いるのが最す簡便であるが，寒郕とし てドライアイスや液体窒素が利用されている。吸着法で は，吸着剂としてシリカゲルやモレキュラシーブスが多用 されるほか，エチレングリコール等む用いられている。こ れらはポンプ等の動力を用いるアクティフ法で行われてき たが，最近モレキュラシーブスを入れた容器の上面に捕集 口を設け, 容器の内外に生じる湿度差により一定の水蒸気 の流れをつくり，吸着剤に捕集するパッシブ法が開発され た(5)。

HT は触媒を用いて酸化し，水として回収する方法が一 般的である。触媒にはパラジゥムをアルミナペレットやモ レキュラシーブスにコーティングしたものや酸化銅が用い られている。パラジゥム触媒は水素を常温で酸化できるの が利点である。大気中の水素存在量は極めて微量 $(0.5$ 
ppm)なので，担体として水素を添加する必要がある。

$\mathrm{CH}_{3} \mathrm{~T}$ は, 白金・アルミナペレット, ホプカライト, 酸化

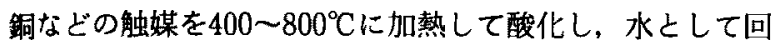
収する方法が用いられている。大気中メタンの存在量む微 量なので，ボンベから担体として添加する必要がある。

大気中のトリチゥムをHTO, HT, $\mathrm{CH}_{3} \mathrm{~T}$ の順に水の形で 分別捕集するための実用的なサンプリング装置のブロック 図を第 V-3 図に示す ${ }^{(6)}$ 。この装置は空気の吸引速度をエ アーポンプ前段のニードルバルブで調整することによっ て, 約 5 時間の急速サンプリングから約 1 カ月の長期間サ ンプリングまで行うことができるように製作されている。

\section{2. 試料水中のトリチウムの濃縮}

現在の環境中トリチウムレベルは低くなっているので， 環境モニタリングの場合でも特に精密測定が要求される場 合には, 試料水中のトリチゥムを濃縮する必要がある。ト リチウムの濃縮法としては, 従来よりアルカリ溶液による 電解濃縮法が用いられてきた。これは水を電気分解した時 に，電極表面において $\mathrm{H}_{2} \mathrm{O}$ はHTOよりも速く分解される ことを利用したもので, 研究機関ごとに独自の装置を開発

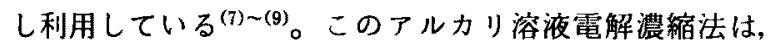
発生する酸素と水素か爆発しやすい比率で出てくるために 危険であることと, 電解濃縮後の高濃度アルカリ溶液の中 和など貺定試料を得る操作や使用㣪の電極の再生などの操 作が複雑で面倒であるという問題点が指摘されている。

これらの問題点を解決するために, 最近陽イオン交換樹 脂膜を利用した固体高分子電解質(Solid Polymer Electrolyte：SPE)法が開発され(10)〜(13)，SPE方式のトリチゥ ム自動濃縮装置も商品化された。SPEは陰イオンが高分 子に固定されていて、水素イオンだけが自由に樹脂内部を 動き回れるようになっている。これを2枚の多孔質電極で 峡んで武料水に浸し，2〜3Vの直流電圧を印加して試料 水の電解を行うと, 軽水素がガスとなって失われ水中には トリチゥムが濃縮されることになる。この方法は爆鳴気が 発生せず安全性が高く, 操作簡単など利点が多いので, 将来的には従来法に置き替わっていくあのと思われる。

\section{3. 液シン用試料調製およびトリチウム測定}

液シン用の試料調製は，試料水と乳化シンチレータを涅 合する乳化法が広く用いられているが，ベンゼン合成法も 利用できる。乳化シンチレータは含水率40～50\%で混合す ることができ，環境モニタリング用として十分な性能を有 している。測定容器は一般にテフロンや低拡散ポリエチレ ン等のバックグラウンドの低いバィアル瓶が用いられる。 ベンゼンは，水とカーバイドの反応によりアセチレンを発 生させ，これを三量化させて合成している。ベンゼンは優 れたシンチレータ溶媒なので，試料調製法としては理想的 であるが，合成に時間がかかるため多数の試料分析には不 向きであり，また 1 回の合成で得られるベンゼンの量は約 $2.5 \mathrm{~m} l$ と少なく, ベンゼン中の水素の割合も約 $8 \%$ と少な いので，環境トリチゥムの測定には乳化法の方が有利であ る。

トリチゥム測定用の計数装置は, 性能がここ10数年来着 実に進歩しており，現在の低バックグラウンド液シン装置 は環境トリチウムのモニタリングを行うのに十分な性能を 有している。

\section{4.ヘリウム同位体法による微量トリチゥム測定}

この方法は，精製した試料水からへリウムの脱がスを 行った㣪，一定期間眝蔵し，その間にトリチウム $\left({ }^{3} \mathrm{H}\right)$ か ら壊変・生成した ${ }^{3} \mathrm{He}$ の量をへリウム質量分析計で定量す ることにより、試料水のトリチウム濃度を測定する方法で ある。脱ガス詝蔵した水量を增やしたり眝蔵期間を長くす れで，検出限界を下げることができるが，水量を多くする と試料水の脱ガスや眝蔵後のへリウム抽出等の操作が難し くなり，また眝蔵期間を長くすると測定までの時間がかか る上，真空漏れ等の原因で大気へリウムの混入を招き，測 定䛊差を大きくするなどの問題が生じる。このため，環境 トリチゥムの分析には液シン計数法の方が有利と考えられ る。しかし，本法は液シン計数法とは测定原理を異にする トリチゥム测定法であるので, 液シン法との相互比較など には有用であり，活用すべきであろう。

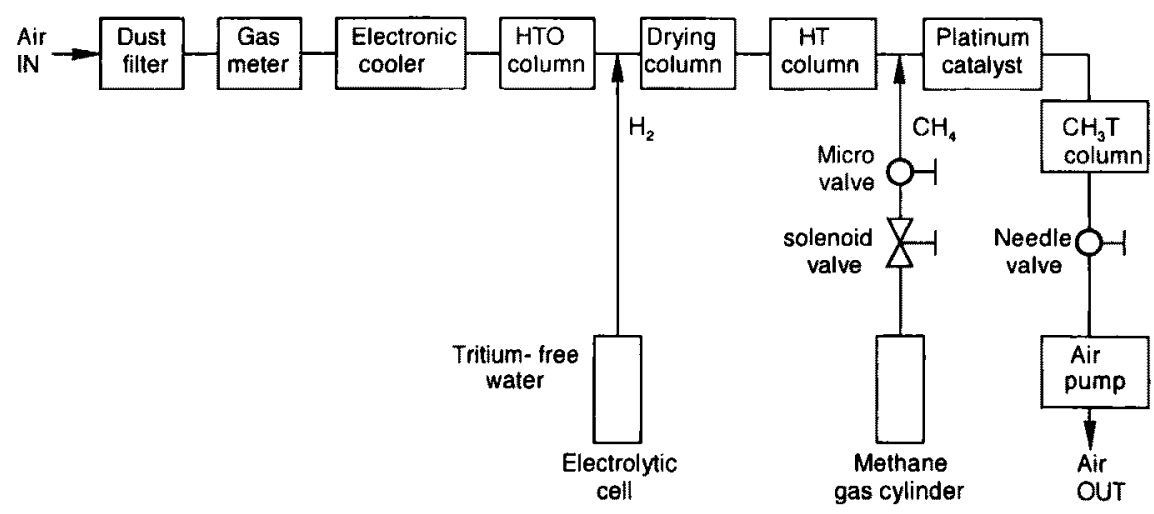

第 V-3 図 大気中トリチウムのサンプリング装置 ${ }^{(6)}$ 


\section{一至考文献—}

(1) Moghissi, A. A., et al. : Anal. Chem., 45, 1565 (1973).

(2) Kakiuchi, H., et al. : Proc. Symp. on Environmental Radioactive Nuclides Impact in Asia, Taipei, 63 (1996).

(3) 岡井富雄, 他：第33回放射化学討論会講演要旨集，3 $02 ， 216$ (1989).

（4）井上義和, 他：第31回放射化学討論会講演要旨集，2B08，154 (1987).

(5) Iida, T., et al. : Proc. 4th Low Level Counting Conference Using Scintillation Analysis, 49 (1994).

(6) Okai, T., Takashima, Y.: J. Radioanal. Nucl. Chem. Articles, 130, 399 (1989).

(7) Florkowski, T. : STI/PUB/592, 335 (1981).

(8) 井上義和: Radioisotopes, 35, 1 (1986).

(9) 加治俊夫, 高島良正 : Radioisotopes, 39, 106 (1990).

(10) 斎藤正明, 他 : Radioisotopes, 45, 285 (1996).

(11) 上松和義, 他: Radioisotopes, 45, 375 (1996)

(12) 斎藤正明, 他：Radioisotopes, 45, 483 (1996).

(13) 斎藤正明：Isotope News, 4 月号, 16 (1997).

\section{V-5 個人モニタリングおよび防謃技術}

\section{日本原子力研究所 山口 武憲*, 野口 宏*}

個人モニタリングの目的は作業者の線量評価とともに, 作業の安全性の確認, 作業環境および作業方法等の改善に 役立てることである。日常モニタリングや作業モニタリン グを適切に実施するとともに，適切な防護方法を選択する ことにより，作業者の慢性的被ばくを防ぎ，潜在的被ばく を低減することができる。

\section{1.トリチウムの化学形と線量への寄与}

トリチウムは摄取する化学形により，体内における残留 割合，すなわち生物的半減期が異なる。ICRP Publ. 56 では, HTO摄取の場合，その $1 \sim 5 \%$ が非揮発性有機化 合物中に取り込まれ，残りは体内水の一部として均一に分 布するとしている。これらの生物的半減期は，それぞれ40 日および10日であり，OBT の線量寄与分は全体の10\%程 度となる。

OBT 摄取の場合, 主に食物として摄取されて体組織中 に吸収される。血液に取り込まれたOBT の半分は体内の 水素と容易に交換され得る成分であり, HTO 上同様の代 謝挙動を示すが、残りの半分は炭素と結合して炭菜の代謝 に従う。炭素と結合した有機成分トリチウムの生物学的半 減期は40日であるため，その線量寄与分は全体の $80 \%$ とな る。

HT の吸入撕取による被ばくについて ICRP Publ. 68 では, 吸入したHTのうち0.01\%がHTOに変換され, 体 内に取り込まれるので，このHTOを被ばくの主要源とし て実効線量係数を求的ている。

* Takenori YAMAGUCHI, Hiroshi NOGUCHI, Japan At. Energy Res. Inst.
原子力施設でのトリチウム取扱い作業におけるトリチウ ム被ばく経路は，HTOあるいはHTの吸入摂取が多いと 考えられる。この場合，体内トリチゥムのほとんどは HTOであり，OBT としての線量寄与分が少ないことや， 測定の簡便性のため，体液中の HTOが全て10日の半減期 で排泄されると仮定して線量を評価している(ICRP Publ. $\left.54^{(3)}\right)$ 。HTOを摄取した日本人の生物学的半減期を調查し た例(4)では，9.4 2.7日であり，ICRPの示す10日とよく 一致しており，線量評価上この10日の半減期を用いること に問題はないと考えられる。なお，より詳細な被ばく評洒 を行うならば，OBTの量を湘定評価して摄取量に加算す る必要がある。しかし，様々な組織に取り込まれた OBT はそれぞれの新陳代謝活動に従うため，各組織中における 残留期間(代謝速度)が異なるので，体内のどの組織をどの ように採取して OBT 量を測定評価するかが難しい。武田 らはラットにOBT(ロイシン,グリシン)を投与し，体毛に 含まれるOBT 濃度之体内の OBT 濃度を測定して両者の関 係を調べ，体毛分析が体内OBT 濃度のモニタリング手段 として有効であることを示唆している(5)。今後，人体内の

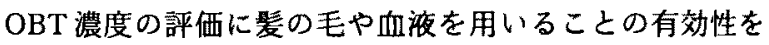
明らかにしていく必要があろう。

\section{2. 試料採取と測定}

HTO あるいはHTの摄取により体内に吸収されたHTO は急速に体内水之混じり，平衡状態(1)(6)となる。トリチウ ム被ばく者の呼気，湩液および尿中トリチウム濃度を50日 間にわたって測定した実験(7)でも，これらの測定值はよい 一致を示していることから，呼気，唾液，尿を試料として测 定することにより体内の HTO 濃度を求めることは妥当と 判断される。

呼気および唾液中トリチウム濃度は吸入摄取の $2 \sim 3 \mathrm{~h}$ 後にはほぼ均一蕽度となる ${ }^{(8)}$ ので，その時点で採取すれ ば良いが, 尿の場合, 膀胱中の尿中トリチゥム濃度が体内 トリチウム濃度と確実に等しくなるには，1 日の平均排尿 回数 6 回(Publ. 68)を考慮すると, 吸入摄取加ら数時間必 要であろう。なお，Publ. 10 $0^{(6)}$ では，その時間を $3 \sim 4 \mathrm{~h}$ としている。

呼気中HTOの採取方法は，ストローやチューブを用い て，呼気をドライアイスや水で领却して採取するコールト トラップ法が一般的である。採取した呼気，唾液を分取し， 液体シンチレータを加えて液体シンチレーションカウンタ で計測する。呼気や唾液はクエンチング(消光作用)が少な いので，一般に用いられている液体シンチレータ(アクア ソル,インスタゲル等)が使用できる。尿試料の場合, 化学 クエンチングやカラークエンチングが測定上の問題となる ので，分取する尿量を少なくするか，蒸留等により尿中の クエンチング物質を除去して測定する必要がある。しか し，近年ではクエンチング抑制効果の高い液体シンチレー 夕が販売されておりそその有効性が確認されている。 


\section{3、トリチウム防護技術}

作業者がトリチウムによって被ばくする経路には吸入， 皮店吸収, 経皮摄取等が考えられる。このうち吸入はHT やHTO等のガス状トリチウムおよび粒子に付着したトリ チゥムなどの浮遊性トリチゥムのすべてについて考えられ る。しかし, 皮覤吸収と経皮捸取はHTO等水溶性のトリ チウムや材料表面に付着したトリチウムについて起こり得 る。このため,トリチウムに対する防護手段を決定するた めには，雾囲気中のトリチウム濃度だけでなく，污染状況 やトリチゥムの物理・化学的形態も考慮する必要がある。

トリチゥム防護手段の代表的なものはスーッや手袋であ る。以下,トリチゥム䇰用気中での作業者の防護に最も有 効なエアラインスーツの開発の現状について述べる。

トリチウム用エアラインスーツの防護性能は，まずスー ッに使用する材質のトリチウム透過率に依存する。種々の 膜のトリチウム透過率や透過パラメータ（透過係数，溶解 度、拡散係数)がこれまでに調べられている(9) (11)。ほとん どの材料ではHTOの透過係数はHTよりあ大きく，例え ば，ポリ塩化ビニールでは40〜100倍大きくなることが報 告されている(9)。これは一般にHTOの方が高分子材料中 の溶解度が大きいためである(10)。しかし，ブチルやネオ プレン等ではHT とHTOの透過係数は同程度か場合に よっては逆転することも報告されている(9)。これまで試験 された膜の中でHTOに対する透過係数の小さい材質は, プラスチック膜ではポリ塩化ビニリデン(サラン,ダゥ・ケ ミカル社)、ゴム膜ではブチルやナイロンーブチルであ $3^{(9) \sim(11)}$ 。

トリチゥム防護用のエアラインスーッの開発および性能 評価は，CANDU炉を多く運転しているカナダで皘極的に 行われてきた。カナダではMark III と呼ばれるポリ塩化ビ ニール製のエアラインスーツが使用されている(12)(13)。こ のスーツのHTOに対する防護係数(防護しない時の被ば く量/防護した時の被ばく量)は約1,000と評価されている。 このスーッの特長は, 空気冷却が可能なこと, 通信機能が 付いていること，低価格で廃㲤可能なフードを使用してい ること，着脱が容易なこと等である。さらに，カナダはド ライクリーニングが可能なエアラインスーッとしてネオプ

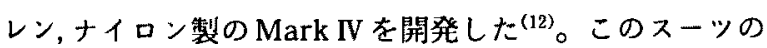
利点は洗浄に使用する液体量が少なく，廃量物星が成少で きることである。

米国のサバンナリバープラントであ，トリチウム用のエ アラインスーツが開発されている(14)。このスーツの材質 にはHTOの透過保数が小さいポリ塩化ビニリデンが使用
されている。ただし、これだけでは耐久性等が久けるた め，塩素化ポリエチレンとエチレン酢酸ビニールとの複層 膜としている。このスーツのトリチウムに対する防護性能 は 1 h 使用時で従来のポリ塩化ビニール製のスーツに比べ て75倍以上可上した。

ヨーロッパのJETでは，自給式呼吸器が接続可能な気 密スーッを備えている(15)。このスーッのHTOに対する防 護係数は 3,500 以上である。このスーツはエアラインがな いので, 動きが自由であるという利点を有するが, 使用時 間が約 $20 \mathrm{~min} に$ 限られる, 熱除去ができない等の欠点が ある。

我が国では，動燃のふげん発電所においてトリチウム用 のエアラインスーッか開発され，使用されている(16)。 のスーツの特徴は，材質にネオプレンゴムを使用している こと, 上下つなぎのウェットスーッ型であること, 空気冷 却により不快感を改善したことなどである。今後, 通話装 置の検討や軽量化が課題とされている。

今後，我が国においても高性能のトリチウム用エアライ ンスーツを開発あるいは導入し、トリチウムに対する作業 者の防護技術を確立する必要がある。このため，第 V-1 節で紹介されている原研の TPL 内に設置予定のトリチウ ム放出模擬試験装置を用いた，エアラインスーツの防護性 能評価実験が現在恰討されている。

\section{一参考文献—}

(1) ICRP : ICRP Publ. 56, Pergamon Press, Oxford, (1989).

(2) ICRP : ICRP Publ.68, Pergamon Press, Oxford, (1994).

(3) ICRP : ICRP Publ. 54, Pergamon Press, Oxford, (1988).

(4) Akaishi, J., et al. : "Radiation-risk-protection", Köln, IRPA. p. 784 787 (1984).

(5) Takeda, H., et al. : Proc. 3rd JAPAN-US Workshop on Tritium Radiobiology and Health Physics, p.99 106 (1988).

(6) ICRP : ICRP Publ. 10, Pergamon Press, Oxford, (1968).

(7) Takada, K, et al. : Health Phys., 41, 825 (1981).

(8) 原研保健物理部等：JAERI-M 6696, (1975).

(9) Fuller, T. P., Easterly, C. E. : ORNL/TM-6671, (1979).

(10) Doughty, D. H. : J. Nucl. Mater., 103 \& 104. 1595 (1981).

(11) Yamamoto, H., et al. : Proc. 8th Int. Radiation Protection Assoc, Vol.1, p.467 (1992).

112 Wong, K. Y., et al. : “Canadian Tritium Experience”, Can. Fusion Fuels Technol. Project, p. 79 82 (1981)

13) Drolet, T. S., Wong, K. Y., Dinner, P. J. : Nucl. Technol./ Fusion, 5, 17 (1984).

(14) Cabbil, C. C. : DP-MS-87-62. (1987).

(15) Russ, R. M., et al. : "Fusion Technology 1992", Proc. 17th Symp. on Fusion Technot., Vol.2, Elsevier Sci. Pub., p.1769 (1993).

(16) 渋谷 進: 保健物理, 18, 283 (1983). 


\section{V. まとめ}

東京大学名誉教授 岡 田 重 文*

我が国の「トリチゥムの影響と安全研究」は，1960年代よ り，核融合研究が開始され，プラズマ研究を中心として進 展，1975年からの核融合開発の総合研究が始まった際に, その一端としてトリチウム技術分科会およびトリチゥム生 物影響分科会か設置されてトリチウム研究が緒についた。

まず，トリチウム取扱い法,トリチウム測定法の開発に 始まり, 国内10数力所の研究室(含む大学, 原研, 放医研な ど)でトリチウム研究が実施できるようになった。我が国 の環境卜リチウムレベルが，大気，河川，湖沼, 海, 雨雪, 水 道水で測定されたばかりでなく，松葉，米，七ト血液などに ついても測定された。またそれらの時期的分布，緯度，水爆 テスト、気象などなど，变動要因が明らかにされた。

本特集においては，環境に放出されたトリチウムが，長 期間にどのようにして大気，土境，農作物に分布し，減衰し て行くか，その後食物連鎖を通じてどのようにヒトに取り 込まれて行くかを緊急課題よして取り上げた。特に，カナ 夕゙における国際共同による 2 回の HT 野外放出実験, 茨城 大における国内共同の HDO 野外放出実験によって，デー 夕が蓄積され，その解析が始まりつつある。特に HT 放出 に際してのHTOへの酸化は土壤細菌のみでなく, 水面で あ起こることが明らかになった。

ヒトへの影響については，データが少ないが，七ト細 胞，マウス細胞，それにマウス個体を用いてのRBE(生物 学的効果比)が得られ, RBEの変動要因も明らかにされて いる。放射線防護の立場からは，1977年のICRP勧告から 1990年勧告の職業人の線量限度值変更を考慮して, 年摄取 限度値を在来值の $1 / 3$ の $1 \times 10^{9} \mathrm{~Bq}$ に変更した(Publ. 61)。 さらに最近(ICRP Publ. 56，68，72)では，ALI(年摂取限 度)の代わりに，線量保数(単位摄取量 $1 \mathrm{~Bq}$ 当たりの実効 線量)を実用上便利な単位として用いることを提案してい る。また，新しい体内動態モデルとして，HTO（体液成 分)に加えて OBT(組織有機成分)の導入, さらに年齢依存 性を導入，また $\mathrm{HT}$ および $\mathrm{CH}_{3} \mathrm{~T}$ の計算も行っている。

トリチゥムの安全評価モデルのプロトタイプとして，原 研において、コード「TRIDOSE」が開発中である。大気へ のHT放出では経口摄取が $98 \%$ と最も大きく，HTO放出 でも83\%であった。経口摸取以外では，HT 放出の場合 で, 土塎酸化後, 大気へ再放出したHTOによる吸入線量 が大きかった。HTOの場合には施設から放出されたHTO の直接吸入による線量が大きかった。

$$
\text { ヒトへの取込みモデルとして「MTCモデル」が開発され }
$$

* Shigebumi OKADA. Prof. Emeritus, Univ. of Tokyo
ているが，経口摄取の経路において，HTO とOBTが異な る経路で取り込まれるとした方が人体のトリチウム代謝の 説明によりよいとしている。

我が国のトリチウム大量取扱施設としては，原研トリチ ウムプロセス研究棟が唯一のグラムレベルのトリチウムを 扱える研究施設である。ここでの安全管理としては, 三重 隔壁格納の考元方を採用し，作業員のトリチウム被ばくの 防止之，周辺環境へのトリチウム放出の低隇化を図ってい る。施設へのトリチウム搬入以来 9 年間たつが，HTO排 気濃度基準の約 $1 / 200$ を維持しており, 年平均積算排出量 は $0.15 \mathrm{Ci} / \mathrm{yr}$ 以下である。

廃棄物管理およひ処理技術： 大規模トリチウム取扱施 設において，トリチウムはまた，ガス(HT, DT, $\mathrm{T}_{2}$ ), 水蒸 気, 水, 有機物, 潤滑油污染, また, 放射化生成核種との複 合污染，など様々な化学的状態で存在している。トリチウ ムの污染もキログラムから軽微な污染と極めて幅広い。污 染による設備, 機器が, その一部あるいは全部が廃棄物と なることも予想される。廃棄の方法も，保管管理加ら，焼 却排気，水希积などなどがあるが，定常時および異常時に ついての検討を要する。

施設内モニタリングおよび環境モニタリングについて は, 問題はなくはないが，ほぼ確立しているといってよか ろう。

個人モニタリンク：今までは，体液(唾液, 尿, 呼気水, 血液)から，体内の HTOが測られ，それからの被ばく線 量評価が行われていた。近年，総被ばく線量の10\%または それ以上の貢献がある OBT(有機成分トリチウム)につい ての関心が高まり，ヒトの毛髪や血液を用いての方法が開 発されている。

トリチウム防讙技術：作業者の作業中の主なトリチウ ム被ばく経路には，経口攝取，吸入摂取，経皮摂取などがあ る。吸入はガス状トリチウム、トリチゥムの付着した浮遊 性粒子などについて考えられる。経皮摂取は，水溶性のト リチゥムや，材料表面に付着したトリチウムとの皮漕接触 によって起きる。これらは手袋や皮唐クリーム塗布で低減 できる。また人体全体の防護手段としてェアラインスーツ か開発されている。

これらの研究は永年にわたって、トリチウムの環境動態 研究者之放射線生物影響研究者加協力し, 相互に研究成果 を反映しつつ、トリチウムの安全研究を目指して走ってき た結果である。核融合・原子力進展のために，国民の理解 と同意を得るために，十分なデー夕を蓄積しておくべきて ある。ミッション・オリエンテッドな研究であり，地道な 成果の皘み重ねを必要とするだけに，核融合研究者・原子 力工学研究者の方々のサポートをぜひお願いしたいもので ある。 